\title{
Cross Talk between Adipose Tissue and Placenta in Obese and Gestational Diabetes Mellitus Pregnancies via Exosomes
}

\author{
Nanthini Jayabalan', Soumyalekshmi Nair', Zarin Nuzhat', Gregory E. Rice, ${ }^{1,2}$, \\ Felipe A. Zuñiga ${ }^{3}$, Luis Sobrevia ${ }^{5,6,7}$, Andrea Leiva ${ }^{5}$, Carlos Sanhueza, \\ Jaime Agustín Gutiérrez ${ }^{4,5}$, Martha Lappas ${ }^{8,9}$, Dilys Jane Freeman ${ }^{10}$ \\ and Carlos Salomon $1,2,3,11^{*}$
}

'Exosome Biology Laboratory, Centre for Clinical Diagnostics, University of Queensland Centre for Clinical Research, Royal Brisbane and Women's Hospital, The University of Queensland, Brisbane, QLD, Australia, ${ }^{2}$ Maternal-Fetal Medicine, Department of Obstetrics and Gynecology, Ochsner Clinic Foundation, New Orleans, LA, United States, ${ }^{3}$ Faculty of Pharmacy, Department of Clinical Biochemistry and Immunology, University of Concepción, Concepción, Chile, ${ }^{4}$ Cellular Signaling and Differentiation Laboratory (CSDL), Medical Technology School, Health Sciences Faculty, Universidad San Sebastian, Santiago, Chile, ${ }^{5}$ Cellular and Molecular Physiology Laboratory (CMPL), Division of Obstetrics and Gynaecology, Faculty of Medicine, School of Medicine, Pontificia Universidad Católica de Chile, Santiago, Chile, ${ }^{6}$ University of Queensland Centre for Clinical Research, Royal Brisbane and Women's Hospital, The University of Queensland, Brisbane, QLD, Australia, ${ }^{7}$ Faculty of Pharmacy, Department of Physiology, Universidad de Sevilla, Seville, Spain, ${ }^{8}$ Obstetrics, Nutrition and Endocrinology Group, Department of Obstetrics and Gynaecology, University of Melbourne, Melbourne, VIC, Australia, ${ }^{9}$ Mercy Perinatal Research Centre, Mercy Hospital for Women, Heidelberg, VIC, Australia, ${ }^{10}$ Institute of Cardiovascular and Medical Sciences, University of Glasgow, Glasgow, United Kingdom, " Mater Research Institute-University of Queensland, Translational Research Institute, Woolloongabba, QLD, Australia

Obesity is an important public health issue worldwide, where it is commonly associated with the development of metabolic disorders, especially insulin resistance (IR). Maternal obesity is associated with an increased risk of pregnancy complications, especially gestational diabetes mellitus (GDM). Metabolism is a vital process for energy production and the maintenance of essential cellular functions. Excess energy storage is predominantly regulated by the adipose tissue. Primarily made up of adipocytes, adipose tissue acts as the body's major energy reservoir. The role of adipose tissue, however, is not restricted to a "bag of fat." The adipose tissue is an endocrine organ, secreting various adipokines, enzymes, growth factors, and hormones that take part in glucose and lipid metabolism. In obesity, the greater portion of the adipose tissue comprises fat, and there is increased pro-inflammatory cytokine secretion, macrophage infiltration, and reduced insulin sensitivity. Obesity contributes to systemic IR and its associated metabolic complications. Similar to adipose tissue, the placenta is also an endocrine organ. During pregnancy, the placenta secretes various molecules to maintain pregnancy physiology. In addition, the placenta plays an important role in metabolism and exchange of nutrients

\footnotetext{
Abbreviations: ADSC, adipose tissue-derived stem cells; BAT, brown adipose tissue; BMI, body mass index; C19MC, chromosome 19 miRNA cluster; ENPP-1, ectonucleotide pyrophosphatase phosphodiesterase-1; ESCRT, endosomal sorting complex required for transport; EVs, extracellular vesicles; EVT, extravillous trophoblasts; FA, fatty acid; FABP4, fatty acid binding protein 4; GDM, gestational diabetes mellitus; GLUT, glucose transporter; HIF, hypoxia-inducible factor; HSP, heat shock protein; IFN- $\gamma$, interferon- $\gamma$; IL, interleukin; IR, insulin resistance; miRNA, microRNA; MSC, mesenchymal stem cells; MVB, multivesicular bodies; MVs, microvesicles; NAFLD, non-alcoholic fatty liver disease; PI3K, phosphatidylinositol 3-kinase; PLAP, placental alkaline phosphatase; ST, syncytiotrophoblast; TGF- $\beta$, transforming growth factor- $\beta$; TNF- $\alpha$, tumor necrosis factor- $\alpha$; VAT, visceral adipose tissue; WAT, white adipose tissue.
} 
between mother and fetus. Inflammation at the placenta may contribute to the severity of maternal IR and her likelihood of developing GDM and may also mediate the adverse consequences of obesity and GDM on the fetus. Interestingly, studies on maternal insulin sensitivity and secretion of placental hormones have not shown a positive correlation between these phenomena. Recently, a great interest in the field of extracellular vesicles (EVs) has been observed in the literature. EVs are produced by a wide range of cells and are present in all biological fluids. EVs are involved in cell-to-cell communication. Recent evidence points to an association between adipose tissue-derived EVs and metabolic syndrome in obesity. In this review, we will discuss the changes in human placenta and adipose tissue in GDM and obesity and summarize the findings regarding the role of adipose tissue and placenta-derived EVs, with an emphasis on exosomes in obesity, and the contribution of obesity to the development of GDM.

Keywords: adipose tissue, extracellular vesicles, adipose tissue-derived exosomes, obesity, gestational diabetes

\section{INTRODUCTION}

Globally, the incidence of obesity has increased tremendously over the years and become a significant and challenging issue to be addressed (1). Obesity is defined as a body mass index (BMI) of $\geq 30 \mathrm{~kg} / \mathrm{m}^{2}$. Obesity-related diseases and health problems are wide-ranging and pose a substantial threat to healthcare services. Cardiovascular diseases (CVD), stroke, high blood pressure, type 2 diabetes (T2D), and certain forms of cancers are among the harmful effects of obesity (2). According to the Centres for Disease Control and Prevention (CDC), between 2011 and 2014 over $36 \%$ of adults were considered obese and the prevalence was much higher in women (38.3\%) compared to men (34.3\%). Obese women have a higher risk of obstetric complications, especially gestational diabetes mellitus (GDM) (3), with population-based studies demonstrating that approximately $50 \%$ of GDM cases are caused by obesity (4). GDM is characterized as hyperinsulinemia and hyperglycemia in the maternal systemic circulation during gestation (5). Globally, GDM affects approximately $9-15 \%$ of all pregnancies and Australia is no exception (6). Although gestational glucose intolerance returns to normal postnatally, women with a history of GDM have a greater risk of developing T2D later in life. In addition, their babies are at an increased risk of becoming overweight with serious metabolic problems in their adult life (7). In fact, a female child of a GDM mother faces a higher possibility of developing GDM during her subsequent confinement, and the cycle continues (8). The need for early diagnosis of GDM is pressing given that the oral glucose tolerance test is the only available gold standard to diagnose GDM at 24-28 weeks of pregnancy (9). However, GDM pathology is mostly only established by the second trimester of pregnancy, meaning that the potential to reverse this condition is limited (10). Thus, understanding its pathophysiology is important in optimizing a treatment plan and achieving an optimal outcome.

Adipose tissue plays an important role in the development of obesity and its related diseases. An increase in the number and size of adipocytes are among the changes that can be observed in obesity (11). Besides these histological changes, adipose tissue undergoes functional changes in obesity that include deregulated secretion of pro-inflammatory cytokines ("adipocytokines") which contribute to the development of insulin resistance (IR) (12).

Recently, it has been shown that adipose tissue membranederived vesicles termed EVs $(13,14)$ are produced. EVs have been extensively studied for their involvement in intercellular communication which usually occurs via the transfer of bioactive molecules, such as proteins, lipids, and RNAs, from their parent cells (15-18). Intercellular communication is an essential part of body processes and they allow for the proper coordination of biological functions as well as enabling the progression of various diseases. The role of adipose tissue EVs may, thus, contribute to the pathophysiology of GDM, particularly in those cases that are also complicated by obesity.

\section{EXTRACELLULAR VESICLES (EVs)}

Extracellular vesicles are membrane-derived vesicles, playing key roles in cell-to-cell communication and conveying molecular signals to cells at proximal as well as distal locations (19, 20). Initially, EVs were regarded as "debris" generated by cells, however, substantial research in this area revealed that these membrane-derived vesicles interact with their target cells and perform crucial modulatory functions in their biological signaling (21-23). EVs comprise a heterogeneous group of vesicles, classified on the basis of their origin, morphology and mode of release into the extracellular milieu. There are three major vesicle populations, namely apoptotic bodies, microvesicles (MV), and exosomes. Apoptotic bodies (0.8-5 $\mu \mathrm{m}$ in diameter) are released from cells undergoing programmed cell death (24). MVs (0.1-0.35 $\mu \mathrm{m}$ in diameter), also known as ectosomes, originate from external budding of the plasma membrane $(25,26)$. The main focus of the current review are the "exosomes" which are nano-sized vesicles (50-120 $\mathrm{nm}$ in diameter) formed from inward budding of late endosomal structures called multivesicular bodies (MVB) and exocytosed via fusion of MVBs with the plasma membrane $(26,27)$. Exosomes are like "fingerprints," 
uniquely reflecting the phenotype of their parent cell. Emerging research reveals their key role in harmonizing and regulating molecular pathways in their recipient cells, shedding light on the pathophysiological mechanisms in various diseases. The initial biogenesis and release of these endocytic nano-sized vesicles are the initial and most critical steps in the exosome signaling pathway for exerting their biological functions in target cells.

\section{Exosomes Characteristics and Biogenesis}

Exosomes are present in almost all biological fluids and have been isolated from a variety of these fluids as well as from cell culture media (28-39). Exosome isolation is an extensive area of research and can be performed by various methods, including differential centrifugation, density gradient centrifugation, size exclusion chromatography, filtration, polymer-based precipitation, immunological separation, and isolation by sieving $(40,41)$. Each method has inherent advantages and disadvantages depending on the downstream applications of the isolated exosomes (42-44).

Exosomes have been described as having a "cup-shaped" morphology in electron microscopy. In addition, exosomes equilibrate at densities between 1.13 and $1.19 \mathrm{~g} / \mathrm{ml}$ on continuous sucrose gradients (39). Identification of exosome specific markers has a vital role in characterizing exosomes and differentiating them from other EVs. These markers are proteins that are specific to the endosomal pathway. These include proteins related to MVB biogenesis, such as Tsg101, Alix, and tetraspanins (CD-63, CD-9, and CD-81); membrane fusion proteins, such as RAB GTPases and Annexins; and signaling molecules, such as cell adhesion molecules, growth factor receptors, and heat shock protein (HSP)-70 and HSP-90 (45-47). The endosomal sorting complex required for the transport (ESCRT) pathway facilitates membrane remodeling and has been implicated in the formation of intraluminal vesicles (48). An ESCRT-independent pathway has also been described as MVBs can be produced in the absence of all four ESCRT complex subunits $(49,50)$. Finally, the release of exosomes to the extracellular milieu occurs by the fusion of the matured MVB with the plasma membrane, mediated by Rab GTPases $(51,52)$. Exosomes are enclosed by the phospholipid bilayer of their parent cell and contain a small fraction of cytoplasm taken up from their cell of origin. Hence, exosomes are loaded with a wide variety of molecules, including proteins, RNAs, lipids, and fragments of genomic DNA (53-55) that are present in the parent cell. Exosomes, when released into the extracellular space, can act proximally but can also enter the circulation and cross physiological barriers, eliciting their actions at distal locations $(30,56,57)$. The biological function of exosomes relies primarily on the interaction between the exosome and its target cell.

\section{Exosome Signalling}

In order to exert their biological functions, exosomes must be taken up and release their contents into the new host cells. Understanding of the mechanisms by which the signals are processed by target cells is still at its infancy. However, a number of key discoveries have been made that aid the understanding of exosome uptake and signaling in the target cells.
Endocytosis of exosomes is via the exosomal trafficking pathway. The endocytosis process can occur via phagocytosis (58) or receptor and raft-mediated endocytosis $(59,60)$. The phagocytosis mechanism occurs mainly in phagocytic cells. Feng et al. (58) demonstrated that RAW 264.7 macrophages cells effectively internalized exosomes derived from K562 and MT4 cell lines. The internalization was actin-mediated and dependent on phosphatidylinositol 3-kinase (PI3K) and dynamin2. Similarly, Tian et al. (61) showed that pancreatic cancer cells internalized exosomes and the engulfed exosomes were shown to merge with endosomes of the recipient cell and potentially transported to neighboring cells (62).

By contrast, receptor-mediated endocytosis can occur via the classical or non-classical pathway. The former occurs via caveolin or clathrin membrane proteins. The exosomes derived from virus-infected cells were demonstrated to be internalized by target cells via caveolin-dependent endocytosis. Knockdown of the CAV1 gene lead to significantly reduced exosome uptake, proving caveolin-mediated endocytosis (63). Bone marrowderived mesenchymal stromal cells were shown to take up PC12 cell-derived exosomes via clathrin-mediated endocytosis and contributed to alterations in gene expression through the transfer of miR-21 (64). Similarly, an investigation of uptake of macrophage-derived exosomes by the BeWo cell line and human trophoblast cells showed that uptake is an endocytic process mediated by clathrin (62). In addition, the uptake of exosomes induced secretion of pro-inflammatory cytokines by the placental cells. This study demonstrates a change in placental phenotype induced by exosomes.

On the other hand, the non-classical endocytic uptake of exosomes can occur independent of membrane proteins. It has been reported that exosome uptake by glioblastoma cells occur via lipid raft-mediated endocytosis and is dependent on extracellular signal-regulated kinase-1/2 and HSP27 (60).

Another form of exosome-cell interaction is the adhesion of exosomes to a potential docking site found on target cells. This mode of interaction is facilitated by the presence of transmembrane proteins on the surface of the exosomes. Dendritic cell-derived exosomes express intercellular adhesion molecule-1, major histocompatibility complex, and co-stimulatory molecules which enable the exosomes to interact with target cells via their respective signaling receptors (65-67).

By interacting with the recipient cells, exosomes potentially transfer their cargo which is capable of regulating the biological function of the recipient cells. This then orchestrates diverse signaling pathways and mediates a broad range of physiological and pathological conditions. Cellular responses to the microenvironment have a decisive role in determining the concentration and content of exosomes. This has opened up new avenues for biomarker discovery and therapeutic interventions (68-70).

\section{Trafficking of Exosomes and Exosomal MicroRNA (miRNA) between Cells}

All cell types in the human body secrete exosomes, including adipose tissue, liver, pancreas, skeletal muscle and placenta during pregnancy. Exosomes released from metabolically active cells 
could effectively coordinate communication between tissues and initiate metabolic reprogramming in the end target organs. This represents a potential platform for the progression of metabolic disease.

Co-incubation of differentiated $\mathrm{C} 2 \mathrm{C} 12$ (muscle cells) with exosomes isolated from $\mathrm{C} 2 \mathrm{C} 12$ pre-treated with fatty acid (FA) induced alteration in the gene and proteins expressions in the muscle cells. This indicates that exosomes transfer the effects of FA between the muscle cells and this could disrupt homeostasis and lead to IR in muscle cells. In the same study, C2C12-derived exosomes were injected into mice and were found distributed in various tissues, including metabolic tissues (71).

By utilizing pancreatic cancer-derived exosomes, Wang et al. (72) demonstrated that the exosomes entered skeletal muscle cells, initiated lipidosis, and inhibited glucose uptake. In addition, the exosomes downregulated the insulin and PI3K/Akt signaling pathway and impaired the activity of their downstream target, glucose transporter (GLUT)4. In a reciprocal experiment, it was shown that exosomes isolated from skeletal muscle of high fat diet fed mice were taken up by MIN6B1 cells and mouse islets. The release of the exosomal miRNA changed the expression of mRNAs and genes of the MIN6B1 cells as well as inducing the proliferation of MIN6B1 and islets (73). This suggests that skeletal muscle-derived exosomes could potentially provoke IR in distant cells via exosomes.

Similarly, IR in muscle cells was observed after co-incubation with macrophages treated with adipose tissue-derived exosomes (74). This suggests that adipose tissue-derived exosomes could act as a mediator for the onset of metabolic disease. The studies reviewed here suggest that exosomes secreted by cells from metabolic tissues can coordinate metabolism among tissues and be an effective initiator of the onset of metabolic disease, including diabetes and GDM during pregnancy.

Although exosomes contained a wide variety of molecules, miRNAs has been the center of attention mainly due to its role in regulating gene expression. The exosomal miRNAs are trafficked from their parent cells and the exosomal profile varies according to the physiological conditions of their parent cells. The chromosome 19 miRNA cluster (C19MC) is a unique group of 58 miRNAs exclusively expressed in the human placenta and in undifferentiated cells $(75,76)$. Growing evidence highlights the presence of these placental-specific miRNAs in exosomes (77, 78). Luo et al. (79) demonstrated that release of C19MC miRNAs is via exosomes and one of the C19MC-encoded miRNA is involved in tumor necrosis factor (TNF)- $\alpha$ signal transduction. miRNA profiling of whole blood and blood-derived exosomes obtained from patients with metabolic syndrome detected similar expression of miR-17, miR-197, miR-509-5p, miR-92a, and miR-320a (80). However, the proportion of exosomal miRNAs is higher than that in their parent cells (81). Interestingly, the exosomal miRNA profile can differ from those of their parent cells (15). The analysis of liver tissue and exosomes (and MV) isolated from a non-alcoholic fatty liver disease (NAFLD) animal model showed enrichment of miR-122 and miR-192 in the vesicles and relative deficiency in the tissue (82).

Hence, the shuttling of miRNAs from parent cells to exosomes involves selective mechanisms. However, there is a paucity of data defining the selective compartmentalization of miRNAs into exosomes.

\section{The Microenvironment Modulates Exosome Profile}

Although exosomes are produced from cells in a constitutive manner, pathophysiological conditions and stress can modulate exosome biogenesis and release. Recent research provides insight into the selective sorting of proteins and miRNAs into exosomes in conditions of physiological change or pathological stimuli, leading to modification of exosome proteome and RNA profile and, thus, mirroring the microenvironment in the parent cell (83-85).

Hypoxia or low oxygen tension is a stress-induced physiological condition and a classical phenotype in several diseases, such as ischemic CVD, malignancies of diverse origins, obesity, preeclampsia, and physiological challenges such as pregnancy. Hypoxia induces the activation of hypoxia-inducible factor (HIF) which is a key mediator in the cellular adaptation to low oxygen concentrations. HIF, a major modulator of exosome biogenesis and HIFmediated intercellular exosome signaling, has been identified in a vast array of physiological and pathological conditions $(86,87)$. Increased endothelial cell migration and angiogenesis is central to the cellular hypoxic response. Increasing evidence suggests the potential relevance of exosomes in mediating these vascular changes. Angiogenic ability has been attributed to exosomes derived from aggressive tumors.

The crucial role of exosomes in remodeling the hypoxiainduced tumor microenvironment has been well elucidated (85, 88-91). Hypoxic tumor exosomes are loaded with unique proteins and have an enhanced capacity for invasiveness, stemness, and tumor progression $(87,92)$. Hypoxia-induced endothelial dysfunction, a major driver of cardiac disease, is mediated by exosomes $(93,94)$. During pregnancy, hypoxia triggered exosome signaling increases placental vasculogenesis and augments cytotrophoblastic invasiveness and proliferation as adaptive mechanisms to protect the fetus from oxidative stress $(95,96)$. In addition, in metabolic disorders such as obesity, exosomes derived from hypoxic adipocytes show an enrichment of lipogenic proteins modulating lipogenic pathways in neighboring adipocytes and pre-adipocytes, thereby transferring characteristics of adipocyte dysfunction (97).

In addition to oxygen tension, the biogenesis and release of exosomes is also affected by glucose concentration. Investigation of the effects of glucose on exosome release showed elevated number of exosomes from trophoblast cells cultured under both high and low glucose concentration $(98,99)$. Furthermore, the released exosomes induced secretion of pro-inflammatory cytokines from endothelial cells (99). This mechanism potentially mediates the maternal pro-inflammatory profile seen in pregnancies with glucose intolerance. Comparison analysis of plasma exosomal miRNA showed upregulation of miR-326 in diabetic patients compared to controls and this increase negatively correlated with its target, adiponectin (100).

However, the exact mechanism of these alterations in exosome biogenesis and of exosomal miRNA profile under different 
extracellular glucose concentration is not completely understood. The current body of data suggests that changes in intracellular $\mathrm{Ca}^{2+}$ concentration may play a vital role in membrane trafficking, fusion, and retrieval and has intriguing roles in modulating exosome release in response to extracellular glucose (101-103).

\section{THE HUMAN PLACENTA}

A healthy pregnancy outcome is highly reliant on tight physiological regulation that is largely orchestrated by an extremely complex and multifunctional materno-fetal organ, the placenta (104). The human placenta is made up of trophoblast cells specifically the cytotrophoblast, syncytiotrophoblast (ST), and extravillous trophoblast (EVT). The ST cells are in direct contact with the maternal circulation (105). Meanwhile, EVT are a specific type of cells with a high invasive capacity; these cells migrate to the maternal tissue to remodel the uterine spiral arteries (106).

The placenta is a highly multifunctional organ. It regulates the exchange of respiratory gases, provides protection for the fetus against maternal immunity, and removes carbon dioxide and excretions from the fetus through the mother. Furthermore, the human placenta acts as a nutrient sensor, controlling maternalfetal nutrient transport $(107,108)$. It detects maternal-fetal nutrient status and alters nutrient transporter capacity to align to fetal growth and nutrient requirements $(109,110)$. In addition, the placenta is a transient endocrine organ secreting various hormones and cytokines that can directly affect both maternal and fetal metabolism.

\section{Placenta in Obesity}

Cytokines and hormones play major roles in the initiation and preservation of pregnancy. However, the endocrine functions of placenta are greatly affected by maternal obesity. Maternal metainflammation produces signals opposing the normal regulatory functions of the placenta and contributes to the adverse outcomes observed in obese pregnant mothers. The increase in maternal BMI has been positively correlated with an increase in placental weight (111). A population-based study showed that obese pregnant women had higher placental weight with higher plasma glucose and leptin than their non-obese counterparts at term (112).

Obese pregnancies have a dysregulated maternal cytokine profile with a significant rise in pro-inflammatory cytokines $(113,114)$. In addition to changes in the plasma, changes to the inflammatory profile of the placenta are also observed in obese pregnancies. An increase in TNF- $\alpha$ turnover in obesity is a wellknown phenomenon. Similarly, reports of a significant elevation of TNF- $\alpha$ in the circulation and placenta of obese mothers are consistent (115-119). The placental production of leptin leads to maternal hyperleptinemia with downregulation of placental leptin receptors and resultant leptin resistance in obese mothers (120-122). The analysis of placentae from obese mothers also showed increases in other pro-inflammatory cytokines, such as interleukin (IL)-1 $\beta$ and IL-6 $(115,117)$. A sequencing study of placental RNA highlighted that levels of IL-12R $\beta 2$, IL-21R, and CX3CR1 were increased while IL-R1, IL-1RAP, CXCR1, CXCR2, CCR3, and ADIPOR1 gene were decreased in placentae of obese women (123).
As a whole, obesity in pregnancy has profound effects, causing systemic inflammation. The increase in circulating pro-inflammatory cytokines from adipose tissue may provoke increased inflammatory cytokines secretion by the placenta and alter placental function. The obesity associated with GDM may have similar or enhanced negative consequences for the placenta.

\section{Placenta in GDM}

Pathologically, GDM is characterized by the onset of glucose intolerance of variable severity that is first recognized during pregnancy (124) and a fasting glycemia level $\geq 92 \mathrm{mg} / \mathrm{ml}$ (125). An increase in IR is commonly due to changes in pregnancyrelated hormones that occur during early gestation (126). The mother's inability to secrete sufficient insulin to counteract the IR induced by the gluconeogenic placental hormones may cause the development of GDM (127).

The human placenta is at the materno-fetal interface. Due to its position, the placenta is greatly exposed to various adverse intrauterine conditions and can easily be affected by any changes in its milleu. Glucose is the primary placental energy substrate. Materno-fetal glucose exchange is vital for fetal survival and is observed throughout pregnancy. The gestational changes in maternal glucose metabolism and increased blood glucose level reflect the maternal metabolic adaptations to fulfill the nutrition requirements of the developing fetus. However, this phenomenon is exacerbated in GDM.

The hyperglycemic condition affects trans-placental glucose transport and dysregulation of GLUT activity. In GDM pregnancies, the expression of GLUT1 at the basal membrane was increased twofold with a $40 \%$ increase in glucose uptake (128). GLUT1 and mTOR signaling were significantly increased in placentae from GDM pregnancies when compared to normal pregnancies. Interestingly, these changes were associated with a $50 \%$ reduction in mitochondrial respiration in trophoblast cells isolated from GDM placentae when compared to the control (i.e., cells from normal placentae) (129). Similarly, utilizing GDM placental explants, a study demonstrated a twofold to threefold increase in glucose uptake (130).

Interestingly, the overexpression of pro-inflammatory cytokines seen in obesity is also observable in GDM placenta. The prominent increase in TNF- $\alpha$ seen in obese pregnancies has also been observed in the maternal circulation and placenta in GDM. The overexpression of TNF- $\alpha$ in GDM placenta is associated with increased fetal adiposity $(131,132)$. Similarly, Kuzmicki et al. (133) and Lepercq et al. (131) reported an increased IL-8 and leptin expression in GDM placenta, respectively.

The current body of literature suggests that maternal inflammation leads to the over-production of inflammatory cytokines by the placenta that would normally be expressed at significantly lower levels in healthy pregnancies. It is proposed that this enhanced inflammation is associated with the metabolic changes seen in GDM pregnancies. Although these data demonstrate an interaction between maternal obesity and the development of GDM, strikingly, the underlying mechanism that could explain why obesity-associated inflammation is transferred or enhanced in obese-GDM placenta is not understood. Therefore, it can be postulated that other factors mediate the development of GDM by influencing placental function. 


\section{Placental Exosomes in Understanding Pregnancy Pathologies}

Besides secreting hormones and cytokines, the placenta extrudes large quantities of EVs (Table 1) constitutively throughout gestation originating mainly from the syncytiotrophoblastic layer $(134,135)$. EVs, especially exosomes, are packed with a vast repertoire of proteins, miRNAs and phospholipids that play crucial roles in maintaining feto-maternal communication for healthy pregnancy outcomes (136). These exosomes can be identified through their molecular features. In particular, human placental alkaline phosphatase (PLAP) is an allosteric enzyme synthesized in the placenta. Exosomes isolated from the circulation of pregnant women carried PLAP on their membranes; hence, a PLAP ${ }^{+}$ phenotype can be used to identify placental origin $(137,138)$.

Maternal plasma is an excellent source for placenta-derived exosomes with their appearance reported as early as 6 weeks of gestation $(138,139)$ with concentrations varying in accordance with the stage of gestation $(135,137,138)$. The presence of immune molecules such as HLA-G and B7 family in PLAP ${ }^{+}$ exosomes demonstrates their role in maternal immunomodulation. This counteracts allograft rejection of the fetus and sustains cellular adaptation in the face of the physiological changes

TABLE 1 | Summary of studies of EVs derived from placental experimental designs.

\begin{tabular}{|c|c|c|c|c|}
\hline EV types & Sample types & Isolation method & Findings & Reference \\
\hline STMB & Plasma & Centrifugation & Presence of high level of EVs in late onset preeclampsia & Dragovic et al. (142) \\
\hline Exosomes & Plasma & $\begin{array}{l}\text { Centrifugation + density } \\
\text { gradient }\end{array}$ & Presence of high levels of placental exosomes in preeclampsia & Pillay et al. (232) \\
\hline STBM & Plasma & $\begin{array}{l}\text { Time-resolved } \\
\text { fluoroimmunoassay }\end{array}$ & STBM increase in preeclampsia & Knight et al. (233) \\
\hline Exosomes & Plasma & $\begin{array}{l}\text { Centrifugation + density } \\
\text { gradient }\end{array}$ & Presence of high levels of placental exosomes in GDM & Salomon et al. (144) \\
\hline Exosomes & $\begin{array}{l}\text { Primary trophoblast cells and } \\
\text { villous explant }\end{array}$ & $\begin{array}{l}\text { Centrifugation + density } \\
\text { gradient }\end{array}$ & Exosomes modulate maternal immune response & Kshirsagar et al. (140) \\
\hline Exosomes & $\begin{array}{l}\text { Villous explants } \\
\text { Primary trophoblast cells and } \\
\text { BeWo cells }\end{array}$ & $\begin{array}{l}\text { Centrifugation + density } \\
\text { gradient }\end{array}$ & Exosomes modulate trophoblast syncytium formation & Tolosa et al. (141) \\
\hline Exosomes & Primary trophoblast cells & $\begin{array}{l}\text { Centrifugation + density } \\
\text { gradient }\end{array}$ & $\begin{array}{l}\text { Hyperglycemia induces release of exosomes and alters their } \\
\text { bioctivity }\end{array}$ & Rice et al. (99) \\
\hline Exosomes & Primary trophoblast cells & $\begin{array}{l}\text { Centrifugation + density } \\
\text { gradient }\end{array}$ & Under hypoxia exosomes mediate trophoblast migration & Salomon et al. (95) \\
\hline Exosomes & $\begin{array}{l}\text { Primary trophoblast cells } \\
\text { JEG-3 } \\
\text { BeWo }\end{array}$ & $\begin{array}{l}\text { Centrifugation + density } \\
\text { gradient }\end{array}$ & C19MC is the predominant miRNA species from placenta & Donker et al. (76) \\
\hline STBM & Dual placenta perfusion system & Ultracentrifugation & $\begin{array}{l}\text { Differential expression and pro-inflammatory activity of MV } \\
\text { proteins in preeclampsia }\end{array}$ & Tannetta et al. (237) \\
\hline STBEV & $\begin{array}{l}\text { Dual placenta lobe perfusion } \\
\text { model }\end{array}$ & Ultracentrifugation & Differential enrichment of EVs from placental perfusate & Dragovic et al. (41) \\
\hline STBM & Dual placenta perfusion system & Ultracentrifugation & Cell-free fetal hemoglobin can change miRNA profile in STBM & Cronqvist et al. (238) \\
\hline
\end{tabular}

STMB, syncytiotrophoblast-derived vesicles; EVs, extracellular vesicles; STBEV, syctiotrophoblast-derived extracellular vesicles; MV, microvesicles; GDM, gestational diabetes mellitus. 
associated with pregnancy $(136,140)$. Placenta-derived exosomes carry Synctin-1 that mediates trophoblastic syncytialisation (141) and regulates endothelial cell migration, thereby sculpting the maternal-fetal circulation (137). Thus, the involvement of PLAP ${ }^{+}$ exosomes in various processes, such as immunomodulation and vascular changes, can explain their several fold increase in the early stages of pregnancy (137). In general, the concentration of EVs is higher in pregnancy compared to non-pregnant states (142). Furthermore, the concentration of EVs varies in the presence of pathophysiological conditions such as preeclampsia (143) and GDM (144). Recent evidence suggests that individuals with GDM, in particular, may have a distinct exosomal profile when compared to those from healthy pregnancies. The total number of exosomes in maternal plasma between 11 and 14 weeks of gestation is up to twofold greater in women who later developed GDM (diagnosis at 22-28 weeks) compared to those who had a normoglycaemic pregnancy (144).

In GDM, an environment of hyperglycemic and oxidative stress induces exosome release (99). Interestingly, the elevation in total exosome concentration in maternal plasma significantly correlates with maternal $\mathrm{BMI}$, whereas the ratio of $\mathrm{PLAP}^{+}$to total exosome number decreases with higher maternal BMI across gestation (145). In GDM, the augmentation in exosome numbers is due to an increase in total exosomes other than $\mathrm{PLAP}^{+}$exosomes (144). However, the source of these extra circulating exosomes present in obese and GDM mothers remains unknown.

Hypoxia and elevated glucose concentrations are the hallmarks of GDM, and this alters the exosome profile and bioactivity. Cytotrophoblasts cultured under different oxygen tensions (1, 3, and $8 \%$ ) showed an increased production of exosomes under low oxygen tension $(1 \%)$, which promoted increased invasion and proliferation of the cells (95). Co-incubation of exosomes with endothelial cells in vitro upregulated the cellular secretion of cytokines. Plasma exosomes isolated from obese and GDM subjects induced the secretion of pro-inflammatory cytokines from endothelial cells from normal and lean pregnancies $(144,145)$. These findings provide some interesting insights into the role of exosomes in the inflammatory phenomena typically associated with GDM.

Exosomal-mediated miRNA signaling is another fascinating scenario of feto-maternal communication, absolutely essential to maintain the physiological and metabolic harmony between the mother and fetus (79). The dysregulated expression of placental-specific C19MC miRNAs is associated with pathological pregnancies including GDM (146-148). Consistent with this, an increase in the expression of C19MC miRNAs in placental exosomes in the presence of high extracellular glucose was reported (78). Therefore, exosomal miRNA may potentially be involved in placental-maternal signaling.

\section{ADIPOSE TISSUE}

Adipose tissue is an inert connective tissue comprised primarily of adipocytes which functions as a fat reservoir. There are two types of adipose tissue, white adipose tissue (WAT) and brown adipose tissue (BAT). Fats are stored as triglycerides and released as free FA whenever the body requires energy. Despite functional differences, the formation of both WAT and BAT is regulated by the process of adipogenesis, which can be divided into two phases. First, this involves the commitment of mesenchymal stem cells (MSC) to becoming preadipocytes followed by the terminal differentiation of preadipocytes into adipocytes (149-152).

Brown adipose tissue is made up of multilocular thermogenic brown adipocytes. The enrichment of iron containing mitochondria and high expression of Uncoupling Protein 1 provides for the thermogenic role of BAT (153). BAT is abundantly present in infants and recent reports demonstrate the presence of functionally relevant BAT in adults (154-156). Interestingly, a high level of BAT activity was associated with low BMI $(157,158)$. This reflects the probable involvement of BAT in energy metabolism, which is seemingly higher in lean individuals.

On the other hand, WAT is made up of unilocular white adipocytes each containing a single lipid droplet. Besides adipocytes, WAT also comprises stromal cells such as preadipocytes, fibroblasts, macrophages, and endothelial cells $(159,160)$. Importantly, WAT is involved in energy storage and there are different depots based on its location in the body. Adipose tissue located beneath the skin is known as the subcutaneous adipose tissue, while visceral adipose tissue (VAT) refers to the fat surrounding internal organs. The link between obesity and metabolic disease is most commonly observed with accumulation of VAT.

Besides its function as a thermal regulator and fat-storage site, adipose tissue is the largest endocrine organ and regulates homeostasis by coordinating intercellular communication with other body systems. Adipose tissue readily modulates various biological functions by producing an array of bioactive peptides known as adipocytokines, which are capable of exerting various metabolic effects including those on glucose and lipid metabolism (161-163).

The discovery of leptin gives adipose tissue the status of an endocrine organ. Leptin, the "satiety hormone," has anorexigenic effects and acts on food intake and fat mass. Leptin, which is involved in energy metabolism, significantly increases in obesity and is present in its free form $(164,165)$. Adiponectin is an adipose tissue-specific adipokine (166) and is well known for its role in energy homeostasis as well as anti-obesity, anti-inflammatory, and anti-diabetic properties (167-169). Adiponectin promotes glucose utilization and fatty acid oxidation (FAO), which enhances insulin sensitivity $(170,171)$. Activation of the AMPactivated protein kinase signaling pathway by adiponectin acts as a central regulator of glucose and lipid metabolism (170).

The imbalance between energy intake and expenditure leads to expansion of adipose tissue. The two possible growth mechanisms are hyperplasia and hypertrophy (172). The hyperplastic expansion generates new adipocytes. Meanwhile, hypertrophy beings about an increase in the size of adipocytes $(173,174)$. The finding that significant weight loss in humans is marked by a reduction in adipocyte volume but not number suggests that adipose tissue hypertrophy is strongly associated with obesity.

\section{ADIPOSE TISSUE IN OBESITY}

Obesity is associated with inflammation, elicited by metabolites which lead to systemic IR. This pro-inflammatory environment 
in obesity, known as "metainflammation," (metabolically induced inflammation) is associated with a reduced metabolic rate, maintained by adipose tissue (175). The adipose tissue of obese individuals is known to comprise a greater fraction of fat as the adipose tissue has the ability to adapt to the nutrient environment and store excess energy.

The hypertrophic expansion of adipocytes causes dysregulation of cytokine secretion and is responsible for the low-grade inflammation and several comorbidities seen alongside obesity. In obese individuals, the production of adiponectin decreases with an expansion of the adipose tissues (176). This has been attributed to the failure of transcriptional regulation (177). Hypermethylation of the adiponectin promoter induced by DNA methyltransferase- 1 is ascribed to the hypoadiponectinemia seen in obesity (178). The decreased expression of adiponectin is seen in conjunction with effects on glucose metabolism and an increase in IR $(176,179)$. Besides adiponectin, the expression of adiponectin receptors, ApoR1 and ApoR2, is reduced in obesity, hence enhancing IR $(180,181)$. Similarly, the abnormal production of leptin in obesity leads to leptin resistance and supresses insulin-stimulated glucose metabolism (182).

In addition, hypertrophic adipocytes secrete elevated amounts of pro-inflammatory cytokines such as TNF- $\alpha$, IL- 6 , IL- 8 , and monocyte chemoattractant protein (MCP) (183-185). The increased secretion of pro-inflammatory cytokines and the relative hypoxia and cell death promoted by hypertrophic adipocytes promotes a high infiltration rate of monocytes into visceral adipose tissue and activation of macrophages (186). Overall, the increase in release of pro-inflammatory cytokines and infiltration of macrophages leads to development of IR (187).

Adipocytokines are known to regulate cellular signaling in various tissues through endocrine mechanisms. However, there is lack of a positive correlation between BMI, adipocytokines, and the development of diabetes in obese pregnancies. In order to further understand these interrelationships, it is necessary to interrogate the potential involvement of adipose tissue-derived exosomes in overall glucose regulation.

\section{Adipose Tissue in GDM}

Maternal body fat mass increases throughout the pregnancy, with accumulation of fat observed on the trunk $(188,189)$. During pregnancy, appropriate expansion of adipose tissue is vital in order to support nutrient supply to the fetus. However, the hypertrophic growth of adipose tissue is closely associated with metabolic abnormalities and IR (190-192). The ectonucleotide pyrophosphate phosphodiesterase-1 (ENPP-1) is a protein known to induce adipocyte IR. In a recent study, it was demonstrated that adipose tissue from obese patients with GDM expresses high level of ENPP-1 that correlates with the expression of GLUT4 and with insulin receptor substrate-1 serine phosphorylation (193).

Hypertrophy of adipocytes in adipose tissue can impair the functions of adipose tissue, overall. Hypertrophic adipose tissue is associated with excess amount of adiposity and results in a dysregulated secretory profile (194). A higher level of proinflammatory cytokines, especially TNF- $\alpha$ and IL- 6 has been reported in obese pregnancies $(195,196)$. The abnormal secretion of adipocytokines is implicated as an essential factor in the development of GDM $(197,198)$.

Studies to date are suggesting that the relationship between hypertrophic growth of adipose tissue and inflammation is a pivotal factor that causes IR. However, the underlying mechanism by which these adipocytokines affect GDM is not fully understood. While our current understanding of GDM is limited to inflammation induced by adipocytokines, a wide variety of adipose tissue functions may be regulated by adipose tissue-derived exosomes. Therefore, the involvement of adipose tissue-derived exosomes in the development in GDM is possible and understanding of this mechanism is essential.

\section{Adipose Tissue-Derived Exosomes}

In addition to soluble factors, exosomes are also involved in various functions of adipose tissue (Table 2). Adipose tissue-derived exosomes have been isolated from culture medium of adipose tissue, adipocytes, and adipose tissue-derived stem cells (ADSC) (74, 199-202). A recent study demonstrated that both 3T3-L1 adipocytes and primary adipocytes secrete large proportions of exosomes (203). In addition, exosomes secreted by adipocytes were reported to be more abundant compared to exosomes secreted by melanoma cells (204). This suggests the probable participation of adipose tissue/adipocyte-derived exosomes in various biological functions.

Although most studies report adipose tissue-derived exosomes within the proposed size range of exosomes (203, 205), Katsuda et al. (206) reported ADSC-derived exosomes that were larger. This indicates that the size range of the exosomes may differ based on the cellular source of isolation. In addition to the identification of exosomal markers, adipose tissue-derived exosomes can be characterized based on the presence of adipose tissue-specific markers, such as fatty acid binding protein 4 (FABP4; adipocyte differentiation marker) and adiponectin $(205,207,208)$.

Interestingly, the characterization of exosomes released preand post-adipogenesis showed differences in the protein content. Pref-1 and FABP4 were decreased while adiponectin was increased in the post-adipogenesis exosomes. However, there were no changes in the exosomal markers, such as CD9, CD63, TSG101, and Alix (13). This shows that proteins, which are commonly used for bio-marking exosomes, can be used to identify the adipose tissue-derived exosomes.

The release of exosomes has been reported to vary depending on body weight. The concentration of exosomes differs between adipose tissue from lean and obese individuals. The quantification of exosomes isolated from subcutaneous and omental ADSC of lean and obese donors showed that ADSC from obese individuals secretes higher concentrations of exosomes (202). Similarly, the primary adipocytes of obese animals secreted more exosomes when compared to lean animals (204). Surprisingly, exosomes isolated from adipose tissue explants derived from lean and obese individuals showed a higher number of exosomes released by lean adipose tissue (205). The secretion of a higher amount of exosomes by lean adipose tissue may be attributed to the fact that there is a higher number of adipocytes in lean adipose tissue. However, a larger proportion of adipose tissue in 
TABLE 2 | Summary of studies of EVs derived from adipose tissue.

\begin{tabular}{|c|c|c|c|c|}
\hline EVs & Source & Isolation method & Findings & Reference \\
\hline Exosomes & Ad-MSC & Centrifugation & $\begin{array}{l}\text { The exosomes showed inhibitory effect in the differentiation and activation of } \\
\mathrm{T} \text { cells and reduced the proliferation and IFN- } \gamma \text { release }\end{array}$ & $\begin{array}{l}\text { Blazquez } \\
\text { et al. (220) }\end{array}$ \\
\hline Exosomes & Ad-MSC & Not specified & $\begin{array}{l}\text { Graft-versus-host disease patients treated with the exosomes showed } \\
\text { reduction in the symptoms }\end{array}$ & Ludwig et al. (221) \\
\hline Exosomes & $\begin{array}{l}\text { Primary culture of } \\
\text { rat adipocytes }\end{array}$ & Centrifugation + filtration & $\begin{array}{l}\text { A total of } 509 \text { proteins were identified, some of which are known to express in } \\
\text { the adipocytes.Comparison of the exosomes derived from obese diabetic and } \\
\text { obese non-diabetic showed differential expression of } 200 \text { proteins }\end{array}$ & Lee et al. (215) \\
\hline $\begin{array}{l}\text { Exosomes and } \\
\text { microvesicles }\end{array}$ & Ad-MSC & Centrifugation & $\begin{array}{l}\text { Comparison between MSCs and EVs showed a total of } 128 \text { proteins were } \\
\text { selectively enriched in the EVs }\end{array}$ & Eirin et al. (213) \\
\hline $\begin{array}{l}\text { Exosomes and } \\
\text { microvesicles }\end{array}$ & Ad-MSC & Centrifugation & $\begin{array}{l}\text { Comparison between MSC and EVs showed enrichment of } 4 \text { miRNAs, } 255 \\
\text { mRNAs, and } 277 \text { proteins enriched in EVs }\end{array}$ & Eirin et al. (214) \\
\hline Exosomes & $\begin{array}{l}\text { Human adipose } \\
\text { tissue }\end{array}$ & Centrifugation & $\begin{array}{l}\text { The exosomes are capable of impairing insulin signaling in the end target } \\
\text { organ depending on the contents }\end{array}$ & $\begin{array}{l}\text { Kranendonk } \\
\text { et al. (207) }\end{array}$ \\
\hline $\begin{array}{l}\text { Exosomes and } \\
\text { microvesicles }\end{array}$ & 3T3-L1 cells & Centrifugation & $\begin{array}{l}\text { The concentration of EVs was higher, pre-adipogenesis and the exosomal } \\
\text { proteins content differ between pre- and post-adipogenesis EVs }\end{array}$ & Connolly et al. (13) \\
\hline Exosomes & $\begin{array}{l}\text { Mice visceral } \\
\text { adipose tissue }\end{array}$ & $\begin{array}{l}\text { Centrifugation + density } \\
\text { gradient }\end{array}$ & $\begin{array}{l}\text { The exosomes released from obese adipose tissue induced the differentiation } \\
\text { of monocytes to macrophages and development of insulin resistance in lean } \\
\text { mice }\end{array}$ & Deng et al. (74) \\
\hline Exosomes & Ad-MSC & Centrifugation & $\begin{array}{l}\text { The exosomes promoted migration and upregulation of cancer-related } \\
\text { signaling pathways in MCF7 }\end{array}$ & Lin et al. (201) \\
\hline Exosomes & 3T3-L1 & Commercial kit & $\begin{array}{l}\text { The exosomes reduced the accumulation of } \mathrm{mHtt} \text { aggregates, improved } \\
\text { mitochondrial dysfunction, and increased the survival of the cells }\end{array}$ & Lee et al. (217) \\
\hline $\begin{array}{l}\text { Exosomes and } \\
\text { microvesicles }\end{array}$ & $\begin{array}{l}\text { 3T3-L1 } \\
\text { Primary culture of } \\
\text { rat adipocytes } \\
\text { Plasma }\end{array}$ & Centrifugation & $\begin{array}{l}\text { Perilipin A is enriched in adipocyte-derived EVs, especially from obese } \\
\text { adipocytes. The expression decreased with reduced calorie diet intervention }\end{array}$ & Eguchi et al. (212) \\
\hline Exosomes & $\begin{array}{l}\text { 3T3-F442A } \\
\text { Mice adipose tissue }\end{array}$ & $\begin{array}{l}\text { Centrifugation + density } \\
\text { gradient }\end{array}$ & $\begin{array}{l}\text { The exosomes promoted the migration of the tumor cells through fatty acid } \\
\text { oxidation }\end{array}$ & Lazar et al. (204) \\
\hline $\begin{array}{l}\text { Exosomes and } \\
\text { microvesicles }\end{array}$ & Ad-MSC & Filtration + centrifugation & $\begin{array}{l}\text { The EVs decreased the apoptosis of the neuronal cells and increased } \\
\text { remyelination and activation of neuroglial precursors }\end{array}$ & $\begin{array}{l}\text { Farinazzo } \\
\text { et al. (218) }\end{array}$ \\
\hline Exosomes & Ad-stromal cells & Commercial kit & $\begin{array}{l}\text { The exosomes protected the NSC-34 cells from oxidative damage and } \\
\text { increased their survival }\end{array}$ & $\begin{array}{l}\text { Bonafede } \\
\text { et al. (219) }\end{array}$ \\
\hline Exosomes & Ad-MSC & Commercial kit & $\begin{array}{l}\text { The miR-122 in the exosomes increased the sensitivity of the hepatocellular } \\
\text { carcinoma cells to chemotherapeutic agents }\end{array}$ & Lou et al. (18) \\
\hline Exosomes & $\begin{array}{l}\text { Human adipose } \\
\text { tissue }\end{array}$ & Commercial kit & $\begin{array}{l}\text { The miRNAs were differentially expressed between lean and obese exosomes } \\
\text { and the obese exosomes induced TGF- } \beta \text { pathway dysregulation in HepG2 } \\
\text { cells }\end{array}$ & Koeck et al. (200) \\
\hline Exosomes & $\begin{array}{l}\text { SGBS } \\
\text { Human adipose } \\
\text { tissue }\end{array}$ & $\begin{array}{l}\text { Centrifugation + density } \\
\text { gradient }\end{array}$ & $\begin{array}{l}\text { The exosomes differentiated the monocytes into macrophages. The } \\
\text { macrophages pre-treated with exosomes from adipose tissue inhibited Akt- } \\
\text { phosphorylation and insulin resistance in adipocytes }\end{array}$ & $\begin{array}{l}\text { Kranendonk } \\
\text { et al. (222) }\end{array}$ \\
\hline Exosomes & $\begin{array}{l}\text { Human adipose } \\
\text { tissue }\end{array}$ & Commercial kit & $\begin{array}{l}\text { The exosomes from obese adipose tissue suppressed the phosphorylation of } \\
\text { Akt in both lean and obese skeletal muscle }\end{array}$ & Park et al. (14) \\
\hline Exosomes & $\begin{array}{l}\text { Human adipose } \\
\text { tissue }\end{array}$ & Commercial kit & $\begin{array}{l}\text { Differentially expressed miRNAs between lean and obese adipose-derived } \\
\text { exosomes targets the TGF- } \beta \text { signaling and Wnt/ } \beta \text {-catenin signaling pathways }\end{array}$ & Ferrante et al. (205) \\
\hline Exosomes & $\begin{array}{l}\text { Urine } \\
\text { Serum }\end{array}$ & Not specified & $\begin{array}{l}\text { The exosomes contained mRNAs targeting the TGF- } \beta \text { signaling which is } \\
\text { associated with airway remodeling }\end{array}$ & Epstein et al. (228) \\
\hline Exosomes & $\begin{array}{l}\text { Plasma } \\
\text { Serum }\end{array}$ & Commercial kit & $\begin{array}{l}\text { The miRNA profile of exosomes changed subsequent to gastric bypass and } \\
\text { improved the insulin resistance }\end{array}$ & Hubal et al. (229) \\
\hline Exosomes & 3T3-L1 & Centrifugation + filtration & $\begin{array}{l}\text { The hypoxic adipocyte-derived exosomes showed altered expression and } \\
\text { increased secretion of proteins compared to normal adipocyte-derived } \\
\text { exosomes }\end{array}$ & Sano et al. (97) \\
\hline
\end{tabular}

Ad-MSC, adipose tissue-derived mesenchymal stem cell; EVs, extracellular vesicles; MSC, mesenchymal stem cells; 3T3-L1, preadipocyte cell line; MCF-7, human breast adenocarcinoma cell line; $\mathrm{mHtt}$, mutant Huntington protein; 3T3-F442A, preadipocyte cell line; Ad-stromal cells, adipose tissue-derived stromal cells; NSC-34, motor neuron-like cells; HepG2, human liver cancer cell line; SGBS, Simpson-Golabi-Behmel syndrome preadipocyte cell strain. 
obese individuals may explain the isolation of higher number of exosomes from obese individuals (205). In addition, the release of adipose tissue-derived exosomes is influenced by the extracellular milieu. Adipose tissue hypoxia is one of the dysfunctional processes seen in adipose hypertrophy which can cause dysregulated secretion of adipocytokines (209). 3T3-L1 adipocytes cultured under hypoxic conditions released a higher amount of exosomes (97). Thus, the nature or condition of their parent cell determines exosome secretion.

\section{Composition of Adipose Tissue-Derived Exosomes}

The contents of adipose tissue-derived exosomes are similar to their parent cell. The characterization of adipose tissue-derived exosomes demonstrated the presence of various adipocytokines, such as adiponectin, leptin, resistin, $\mathrm{TNF}-\alpha$, and various ILs that can be found in the adipose tissue (210). Adipose tissuederived exosomes are also enriched with enzymes, such as acetyl-CoA carboxylase, glucose-6-phosphate dehydrogenase, FA synthase, and lipids $(13,97,211)$. Interestingly, the levels of these enzymes were found to be upregulated in obesity (97). Comparison of the circulating vesicles from adipose tissue before and after a reduced calorie diet intervention showed a decreased enrichment of perilipin-A in the vesicles (212). Thus, analysis of the composition of adipose tissue-derived exosomes will be an effective reflection of the metabolic state of the adipose tissue.

Besides reflecting their parent cell, the contents of exosomes act as an important component in coordinating functions and influencing the behavior of the end target cells. In addition, their contents can reflect the microenvironment of the exosomes. In relation to this, the analysis of the composition of overall adipose tissue MSC-derived EVs showed selective enrichment of 128 proteins compared to the adipose tissue MSC (213). Another study demonstrated selective enrichment of 4 miRNAs, 255 mRNAs, and 277 proteins enriched in these EVs (214). Exosomes isolated from hypoxic conditions showed upregulated expression of lipogenic enzymes (97). The proteomic analysis of adipose tissue-derived exosomes isolated from obese-diabetic and obesenon-diabetic rats showed the presence of 509 proteins. Among these proteins, 200 proteins were dysregulated in exosomes isolated from adipose tissue of obese-diabetic rats (215). The dysregulated proteins have been shown to be similarly dysregulated in T2D $(215,216)$. The changes in proteomic content of adipose tissue-derived exosomes reflect the condition of obesity and its related comorbidities. Therefore, characterization and quantification of the contents of the exosomes will provide insight into the health status of the adipose tissue and reflect their involvement in various biological functions.

\section{Biological Properties of Adipose Tissue-Derived Exosomes}

Adipose tissue-derived exosomes are heterogeneous in function and act in both an autocrine and a paracrine manner. Based on these roles, recent findings demonstrate that adipose tissue-derived exosomes may be an underlying mechanism for the regulation of various biological functions and progression of various diseases.
The treatment of the Huntington's disease cell line with ADSC-derived exosomes reduced the $\mathrm{mHtt}$ aggregates and saved the cells from apoptosis (217). The exosomes were also shown to be involved in nerve regeneration. The exosomes inhibited neuronal cell death and promoted re-myelination and re-genesis of neurons (218). In addition, the exosomes increased the viability of the neuron-like cells expressing amyotrophic lateral sclerosis mutation (219). Hence, adipose tissue-derived exosomes have complex functions in the regulation of nerves and neurons, and more broadly, are implicated in progression disease states. This is also supported by the role of adipose tissue-derived exosomes in immune regulation. Exosomes from ADSC impaired the proliferation rate of $\mathrm{T}$ cells and inhibited the activation by reducing the secretion of IFN- $\boldsymbol{\gamma}$ (220). Meanwhile, the exosomes from MSC temporarily improved the symptoms in graft-versus-host disease patients (221). Overall, the current body of literature highlights multifaceted roles for adipose tissue-derived exosomes and multiple key areas in which these exosomes regulate biological function.

Adipose tissue-derived exosomes have been reported to promote tumor growth. The treatment of the MCF7 breast cancer cell line with exosomes derived from ADSC showed greater migration via activation of the Wnt signaling pathway (201). The melanoma cells incubated with exosomes secreted by the 3T3-F442A cells exhibited enhanced migration capacity. The exosomes, which were enriched with trifunctional enzyme subunit $\alpha$, mitochondrial and hydroxyacyl-coenzyme-A-dehydrogenase, escalated FAO regulating tumor progression (204). Given the involvement of adipose tissue-derived exosomes in the progression and development of tumors, targeting this will be an essential aspect in cancer treatment. Cancer therapy is a key area of interest, as adipose tissue-derived exosome have also been used as carriers of specific cargo. Exosomes from miR-122 transfected adipose tissue MSC showed expression of the miRNA. The exosomes then delivered the miRNA to carcinoma cells, increasing their sensitivity to chemotherapeutic agents (18).

Similar to adipose tissue, adipose tissue-derived exosomes are involved in metabolic regulation. Incubation of monocytes with adipocyte-derived exosomes resulted in differentiation of the monocytes into macrophages with upregulation of proinflammatory genes. The macrophages also inhibited phosphorylation of Akt in the adipose tissue (222). The inflammatory role of adipose tissue-derived exosomes is exaggerated in obesity and plays a major role in development of obesity-related diseases, mainly in systemic IR. The injection of adipose tissuederived exosomes into mice showed uptake by monocytes, differentiation into activated macrophages, and secretion of higher amounts of pro-inflammatory cytokines. In the same study, the C2C12 culture treated with adipose tissue-derived exosomesconditioned media showed impaired activation of the insulin response (74). The exosomes derived from obese adipose tissue suppressed Akt-phosphorylation in both lean and obese skeletal muscle cells.

Intriguingly, the effects of adipose tissue-derived exosomes can be cell specific. Stimulation of HepG2 and C2C12 cells with adipose tissue-derived exosomes caused IR by inhibiting Akt-phosphorylation. However, this effect was more prominent 
in the liver cells. Furthermore, the adipocytokine content of the adipose tissue-derived exosomes determined the degree of Akt inhibition (207). The activation of transforming growth factor (TGF)- $\beta$ is related to the development of NAFLD (223). Co-incubation of exosomes from obese adipose tissue-derived exosomes with HepG2 cells caused hyperstimulation of TGF- $\beta$ (200).

Overall, these data support a role of adipose tissue-derived exosomes in mediating signaling in the end organ. Since the regulation of the signaling pathways are mediated by miRNAs, profiling of adipose tissue-derived exosome miRNA contents is essential in further understanding in this unique mode of cellcell communication.

\section{Adipose Tissue-Derived Exosomal miRNA}

Exosomal miRNAs have been identified as novel and promising biomarkers for the diagnosis and prognosis of various diseases. miRNA in adipose tissue-derived exosomes plays a major role in regulating gene expression in adipose tissue as well as in distant cells. A previous study showed the presence of 143 adipocytespecific miRNAs in adipose tissue-derived exosomes isolated from mice adipose tissue (199). In a recent study, the profiling of adipose tissue-derived exosomes isolated from mice serum detected 653 miRNAs. In addition, fat transplantation from wild-type mice to ADicer knock out mice showed restoration of approximately $50 \%$ of circulating miRNAs (224). This shows that miRNAs in adipose tissue-derived exosomes contribute to a large amount of circulating exosomal miRNAs. This also points to involvement in regulating various biological functions in adipose tissue and distant cells.

The miRNAs involved in adipogenesis are among the abundant miRNAs in adipose tissue-derived exosomes. Among the adipogenic miRNA found in adipose tissue-derived exosomes are miR-103, miR-146-b, and miR-148-a (225-227). However, obesity and its related diseases influence the expression of exosomal miRNAs. The profiling of the adipose tissue-derived exosomes isolated from lean and obese individuals showed the differential expression of $88 \mathrm{miRNAs}$ with significant upregulation of miR-23-b and miR-4429. These miRNAs were shown to activate the TGF- $\beta$ and Wnt/ $\beta$-catenin signaling pathways in the end target organs, causing obesity-related conditions (205). Adipose-derived exosomes isolated from serum and urine of obese youths with physician-diagnosed asthma showed differential expression of miRNAs (miR-15a-5p, miR-153-3p, and miR-138-5p) which target TGF- $\beta$ signaling and is associated with poor asthma outcome (228). Adipose tissue exosomal

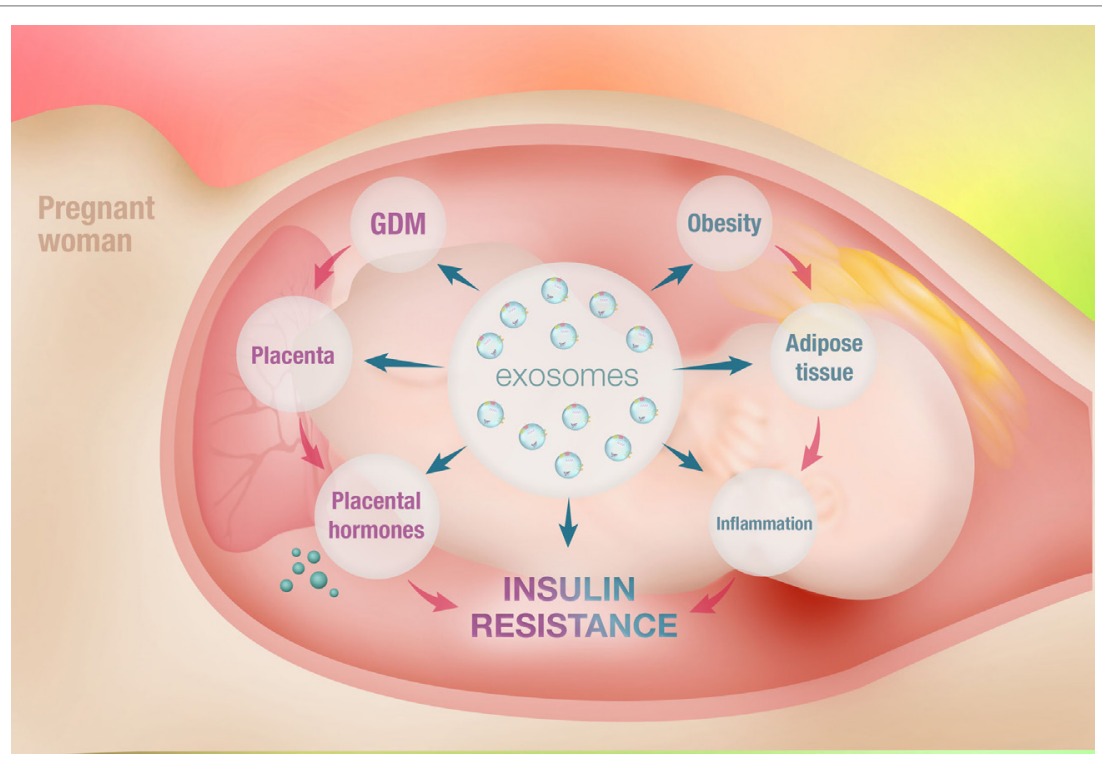

FIGURE 1 | Schematic diagram of intercellular communication between adipose tissue and placenta mediated by adipose tissue-derived exosomes. Obesity refers to an accumulation of excessive fat in adipose tissue due to an imbalance between energy intake and expenditure. This causes hypertrophic expansion of adipocytes and abnormalities in physiological regulation. This is associated with increased free fatty acid release, activation of macrophages, and secretion of elevated amount of pro-inflammatory cytokines, causing systemic inflammation. This is known as metabolically induced inflammation. The marked increase in systemic inflammation is associated with the development of obesity-induced insulin resistance. Gestational diabetes mellitus (GDM) is glucose intolerance diagnosed for the first time during pregnancy. Placental morphological changes as well as altered placental metabolic status are observed in GDM. The placental dysfunction seen in GDM represents an adaptation of the placenta to increased maternal inflammation and results in increased secretion of inflammatory cytokines, further exacerbating inflammation. This potentially causes impairment in insulin sensitivity and development of GDM. However, the evolving concept of maternal obesity and inflammation may not be the full story in the development of GDM. This is due to insufficient data supporting a role for inflammatory cytokines as an initiator of insulin resistance in pregnancy. Interestingly, the various functions of adipose tissue are also orchestrated by the exosomes. Exosomes are mediators of intercellular communication and are capable of regulating cellular mechanisms. Exosomes from adipose tissue are known to regulate the metabolic activity of various cells via paracrine mechanisms. In obesity, adipose tissue-derived exosomes cargo profiles are dysregulated and mediate obesity-associated diseases, including insulin resistance. Thus, it is fair to speculate that the adipose tissue-derived exosomes potentially mediate the communication between adipose tissue and placenta, playing an important role in the development of GDM. 
miRNAs are also associated with development of IR. The analysis of adipose tissue-derived exosomal miRNA content pre- and post-gastric bypass showed upregulation of miR103-3p which is known to target the insulin receptor signaling pathway and was previously found to be downregulated in diabetes (229-231).

These studies demonstrate that adipose tissue-derived exosomes and their content can mediate gene regulation and functioning in distant cells. Therefore, in obese pregnancies, adipose tissue-derived exosomes may communicate with the placenta and induce changes in its function which may contribute to the development of GDM. Thus, it is possible that adipose tissue-derived exosomes are the primary factor in the pathogenesis of GDM.

\section{CONCLUSION}

Exosomes are currently a prominent research interest owing to their unique role in intracellular communication and signaling. In addition, exosomes transport bioactive molecules, such as proteins, lipids, mRNAs, and miRNAs. Exosomal miRNA is a notable feature of exosomes that results in the transfer of the genetic material from one cell to another. This functional mechanism has important relevance in the pathogenesis of various diseases, particularly obesity and GDM (Figure 1).

The IR seen in obesity is maintained by adipose tissue. The dysregulated secretion of bioactive molecules by hypertrophic adipose tissue contributes to the development of IR in obese patients. Besides adipocytokines, the adipose tissue also releases exosomes, which are known to mediate IR and various metabolic disorders associated with obesity. Obesity is an underlying mechanism for the development of GDM. In addition, adipose tissue-derived exosomes are altered in metabolic disorders. Hence, we can postulate that the dysregulated secretion of adipose

\section{REFERENCES}

1. Kopelman PG. Obesity as a medical problem. Nature (2000) 404:635-43. doi: $10.1038 / 35007508$

2. Pi-Sunyer FX. The obesity epidemic: pathophysiology and consequences of obesity. Obes Res (2002) 10(Suppl 2):97s-104s. doi:10.1038/oby.2002.202

3. Chu SY, Callaghan WM, Kim SY, Schmid CH, Lau J, England LJ, et al. Maternal obesity and risk of gestational diabetes mellitus. Diabetes Care (2007) 30:2070-6. doi:10.2337/dc06-2559a

4. Kim SY, England L, Wilson HG, Bish C, Satten GA, Dietz P. Percentage of gestational diabetes mellitus attributable to overweight and obesity. Am J Public Health (2010) 100:1047-52. doi:10.2105/AJPH.2009.172890

5. Kaaja R, Rönnemaa T. Gestational diabetes: pathogenesis and consequences to mother and offspring. Rev Diabet Stud (2008) 5:194-202. doi:10.1900/ RDS.2008.5.194

6. Ferrara A. Increasing prevalence of gestational diabetes mellitus: a public health perspective. Diabetes Care (2007) 30(Suppl 2):S141-6. doi:10.2337/ dc07-s206

7. Rooney BL, Schauberger CW. Excess pregnancy weight gain and long-term obesity: one decade later. Obstet Gynecol (2002) 100:245-52. doi:10.1016/ S0029-7844(02)02125-7

8. Herring SJ, Oken E. Obesity and diabetes in mothers and their children: can we stop the intergenerational cycle? Curr Diab Rep (2011) 11:20-7. doi:10.1007/s11892-010-0156-9

9. Salomon C, Westermeier F, Puebla C, Arroyo P, Guzman-Gutierrez E, Pardo F, et al. Gestational diabetes reduces adenosine transport in human tissue-derived exosomes plays a pivotal role in the development of GDM in obese mothers.

Hypertrophic adipose tissue may cause differential expression of exosomal miRNA. This may further contribute to the systemic inflammation and IR seen in obese GDM pregnancies. This may also alter placental metabolism and nutrient uptake status by deregulating the placental nutrient signaling pathways. Overall, investigating the adipose tissue-derived exosomes present in maternal circulation of obese GDM pregnancies will provide a novel approach to further elucidate the pathophysiology of GDM.

\section{AUTHOR CONTRIBUTIONS}

NJ, SN, ZN, and CS conducted a review of the literature. GER, FZ, LS AL, JG, CSAN, ML and DF critically reviewed the manuscript.

\section{ACKNOWLEDGMENTS}

The authors acknowledge the editorial assistance of Debbie Bullock (UQ Centre for Clinical Research, The University of Queensland). CS and NJ hold a Lions Medical Research Fellowship and Scholarship from the Public Service Department of the Malaysian Government, respectively.

\section{FUNDING}

This study was supported by Lions Medical Research Foundation, UQ-Ochsner Seed Fund for Collaborative Research, The University of Queensland, Faculty of Medicine M + BS Emerging Leaders Medical Research Grant, and Fondo Nacional de Desarrollo Científico y Tecnológico (FONDECYT 1170809 and 1150377).

placental microvascular endothelium, an effect reversed by insulin. PLoS One (2012) 7:e40578. doi:10.1371/journal.pone.0040578

10. Agarwal MM, Weigl B, Hod M. Gestational diabetes screening: the low-cost algorithm. Int J Gynaecol Obstet (2011) 115(Suppl 1):S30-3. doi:10.1016/ S0020-7292(11)60009-X

11. Coppack SW. Adipose tissue changes in obesity. Biochem Soc Trans (2005) 33:1049-52. doi:10.1042/BST20051049

12. Poulos SP, Hausman DB, Hausman GJ. The development and endocrine functions of adipose tissue. Mol Cell Endocrinol (2010) 323:20-34. doi:10.1016/j. mce.2009.12.011

13. Connolly KD, Guschina IA, Yeung V, Clayton A, Draman MS, Von Ruhland C, et al. Characterisation of adipocyte-derived extracellular vesicles released pre- and post-adipogenesis. J Extracell Vesicles (2015) 4:29159. doi:10.3402/ jev.v4.29159

14. Park S, Zheng D, Barberio M, Hubal M, Houmard J. Adipose-derived exosomes from severely obese individuals regulate skeletal muscle metabolism. FASEB J (2016) 30:1245.32

15. Valadi H, Ekstrom K, Bossios A, Sjostrand M, Lee JJ, Lotvall JO. Exosomemediated transfer of mRNAs and microRNAs is a novel mechanism of genetic exchange between cells. Nat Cell Biol (2007) 9:654-9. doi:10.1038/ ncb1596

16. Thery C, Ostrowski M, Segura E. Membrane vesicles as conveyors of immune responses. Nat Rev Immunol (2009) 9:581-93. doi:10.1038/nri2567

17. Lee Y, El Andaloussi S, Wood MJ. Exosomes and microvesicles: extracellular vesicles for genetic information transfer and gene therapy. Hum Mol Genet (2012) 21:R125-34. doi:10.1093/hmg/dds317 
18. Lou G, Song X, Yang F, Wu S, Wang J, Chen Z, et al. Exosomes derived from miR-122-modified adipose tissue-derived MSCs increase chemosensitivity of hepatocellular carcinoma. J Hematol Oncol (2015) 8:122. doi:10.1186/ s13045-015-0220-7

19. Raposo G, Stoorvogel W. Extracellular vesicles: exosomes, microvesicles, and friends. J Cell Biol (2013) 200:373-83. doi:10.1083/jcb.201211138

20. Thery C, Zitvogel L, Amigorena S. Exosomes: composition, biogenesis and function. Nat Rev Immunol (2002) 2:569-79. doi:10.1038/nri855

21. Al-Nedawi K, Meehan B, Micallef J, Lhotak V, May L, Guha A, et al. Intercellular transfer of the oncogenic receptor EGFRvIII by microvesicles derived from tumour cells. Nat Cell Biol (2008) 10:619-24. doi:10.1038/ncb1725

22. Corrado C, Raimondo S, Saieva L, Flugy AM, De Leo G, Alessandro R. Exosome-mediated crosstalk between chronic myelogenous leukemia cells and human bone marrow stromal cells triggers an interleukin 8-dependent survival of leukemia cells. Cancer Lett (2014) 348:71-6. doi:10.1016/j. canlet.2014.03.009

23. Taylor DD, Gerçel-Taylor C. Tumour-derived exosomes and their role in cancer-associated T-cell signalling defects. Br J Cancer (2005) 92:305-11. doi:10.1038/sj.bjc.6602316

24. Hristov M, Erl W, Linder S, Weber PC. Apoptotic bodies from endothelial cells enhance the number and initiate the differentiation of human endothelial progenitor cells in vitro. Blood (2004) 104:2761-6. doi:10.1182/ blood-2003-10-3614

25. Cocucci E, Meldolesi J. Ectosomes and exosomes: shedding the confusion between extracellular vesicles. Trends Cell Biol (2015) 25:364-72. doi:10.1016/j. tcb.2015.01.004

26. Meldolesi J. Ectosomes and exosomes-two extracellular vesicles that differ only in some details. Biochem Mol Bio J (2016) 2.

27. Stremersch S, De Smedt SC, Raemdonck K. Therapeutic and diagnostic applications of extracellular vesicles. J Control Release (2016) 244(B):167-83. doi:10.1016/j.jconrel.2016.07.054

28. Aalberts M, Van Dissel-Emiliani FM, Van Adrichem NP, Van Wijnen M, Wauben $\mathrm{MH}$, Stout TA, et al. Identification of distinct populations of prostasomes that differentially express prostate stem cell antigen, annexin A1, and GLIPR2 in humans. Biol Reprod (2012) 86:82. doi:10.1095/ biolreprod.111.095760

29. Andre F, Schartz NE, Movassagh M, Flament C, Pautier P, Morice P, et al. Malignant effusions and immunogenic tumour-derived exosomes. Lancet (2002) 360:295-305. doi:10.1016/S0140-6736(02)09552-1

30. Caby MP, Lankar D, Vincendeau-Scherrer C, Raposo G, Bonnerot C. Exosomal-like vesicles are present in human blood plasma. Int Immunol (2005) 17:879-87. doi:10.1093/intimm/dxh267

31. Masyuk AI, Huang BQ, Ward CJ, Gradilone SA, Banales JM, Masyuk TV, et al. Biliary exosomes influence cholangiocyte regulatory mechanisms and proliferation through interaction with primary cilia. Am J Physiol Gastrointest Liver Physiol (2010) 299:G990-9. doi:10.1152/ajpgi.00093.2010

32. Michael A, Bajracharya SD, Yuen PST, Zhou H, Star RA, Illei GG, et al. Exosomes from human saliva as a source of microRNA biomarkers. Oral Dis (2010) 16:34-8. doi:10.1111/j.1601-0825.2009.01604.x

33. Pisitkun T, Shen RF, Knepper MA. Identification and proteomic profiling of exosomes in human urine. Proc Natl Acad Sci U S A (2004) 101:13368-73. doi:10.1073/pnas.0403453101

34. Vella LJ, Greenwood DL, Cappai R, Scheerlinck JP, Hill AF. Enrichment of prion protein in exosomes derived from ovine cerebral spinal fluid. Vet Immunol Immunopathol (2008) 124:385-93. doi:10.1016/j.vetimm.2008.04.002

35. Blanchard N, Lankar D, Faure F, Regnault A, Dumont C, Raposo G, et al. Tcr activation of human T cells induces the production of exosomes bearing the TCR/CD3/zeta complex. J Immunol (2002) 168:3235-41. doi:10.4049/ jimmunol.168.7.3235

36. Johnstone RM, Adam M, Hammond JR, Orr L, Turbide C. Vesicle formation during reticulocyte maturation. Association of plasma membrane activities with released vesicles (exosomes). J Biol Chem (1987) 262:9412-20.

37. Knickelbein JE, Liu B, Arakelyan A, Zicari S, Hannes S, Chen P, et al. Modulation of immune responses by extracellular vesicles from retinal pigment epithelium. Invest Ophthalmol Vis Sci (2016) 57:4101-7. doi:10.1167/ iovs.15-18353

38. Raposo G, Nijman HW, Stoorvogel W, Liejendekker R, Harding CV, Melief CJ, et al. B lymphocytes secrete antigen-presenting vesicles. J Exp Med (1996) 183:1161-72. doi:10.1084/jem.183.3.1161
39. Thery C, Amigorena S, Raposo G, Clayton A. Isolation and characterization of exosomes from cell culture supernatants and biological fluids. Curr Protoc Cell Biol (2006) 3:3.22. doi:10.1002/0471143030.cb0322s30

40. Greening DW, Xu R, Ji H, Tauro BJ, Simpson RJ. A protocol for exosome isolation and characterization: evaluation of ultracentrifugation, density-gradient separation, and immunoaffinity capture methods. Methods Mol Biol (2015) 1295:179-209. doi:10.1007/978-1-4939-2550-6_15

41. Dragovic RA, Collett GP, Hole P, Ferguson DJ, Redman CW, Sargent IL, et al. Isolation of syncytiotrophoblast microvesicles and exosomes and their characterisation by multicolour flow cytometry and fluorescence nanoparticle tracking analysis. Methods (2015) 87:64-74. doi:10.1016/j.ymeth.2015.03.028

42. Hong CS, Funk S, Muller L, Boyiadzis M, Whiteside TL. Isolation of biologically active and morphologically intact exosomes from plasma of patients with cancer. J Extracell Vesicles (2016) 5:29289. doi:10.3402/jev.v5.29289

43. Lasser C, Eldh M, Lotvall J. Isolation and characterization of RNA-containing exosomes. J Vis Exp (2012) 59:e3037. doi:10.3791/3037

44. Rani S, O'brien K, Kelleher FC, Corcoran C, Germano S, Radomski MW, et al. Isolation of exosomes for subsequent mRNA, microRNA, and protein profiling. Methods Mol Biol (2011) 784:181-95. doi:10.1007/978-1-61779-289-2_13

45. Campanella C, Bucchieri F, Merendino AM, Fucarino A, Burgio G, Corona DFV, et al. The odyssey of Hsp60 from tumor cells to other destinations includes plasma membrane-associated stages and Golgi and exosomal proteintrafficking modalities. PLoS One (2012) 7:e42008. doi:10.1371/journal. pone. 0042008

46. Clayton A, Turkes A, Dewitt S, Steadman R, Mason MD, Hallett MB. Adhesion and signaling by $B$ cell-derived exosomes: the role of integrins. FASEB J (2004) 18:977-9. doi:10.1096/fj.03-1094fje

47. Mathew A, Bell A, Johnstone RM. Hsp-70 is closely associated with the transferrin receptor in exosomes from maturing reticulocytes. Biochem J (1995) 308:823-30. doi:10.1042/bj3080823

48. Colombo M, Moita C, Van Niel G, Kowal J, Vigneron J, Benaroch P, et al. Analysis of ESCRT functions in exosome biogenesis, composition and secretion highlights the heterogeneity of extracellular vesicles. J Cell Sci (2013) 126:5553-65. doi:10.1242/jcs.128868

49. Trajkovic K, Hsu C, Chiantia S, Rajendran L, Wenzel D, Wieland F, et al. Ceramide triggers budding of exosome vesicles into multivesicular endosomes. Science (2008) 319:1244-7. doi:10.1126/science.1153124

50. Stuffers S, Sem Wegner C, Stenmark H, Brech A. Multivesicular endosome biogenesis in the absence of ESCRTs. Traffic (2009) 10:925-37. doi:10.1111/j.16000854.2009.00920.x

51. Savina A, Vidal M, Colombo MI. The exosome pathway in K562 cells is regulated by Rab11. J Cell Sci (2002) 115:2505-15.

52. Ostrowski M, Carmo NB, Krumeich S, Fanget I, Raposo G, Savina A, et al. Rab27a and Rab27b control different steps of the exosome secretion pathway. Nat Cell Biol (2010) 12:19-30; sup pp 1-13. doi:10.1038/ncb2000

53. Kowal J, Tkach M, Thery C. Biogenesis and secretion of exosomes. Curr Opin Cell Biol (2014) 29:116-25. doi:10.1016/j.ceb.2014.05.004

54. Keller S, Sanderson MP, Stoeck A, Altevogt P. Exosomes: from biogenesis and secretion to biological function. Immunol Lett (2006) 107:102-8. doi:10.1016/j. imlet.2006.09.005

55. Yanez-Mo M, Siljander PR, Andreu Z, Zavec AB, Borras FE, Buzas EI, et al. Biological properties of extracellular vesicles and their physiological functions. J Extracell Vesicles (2015) 4:27066. doi:10.3402/jev.v4.27066

56. Sheller-Miller S, Lei J, Saade G, Salomon C, Burd I, Menon R. Feto-maternal trafficking of exosomes in murine pregnancy models. Front Pharmacol (2016) 7:432. doi:10.3389/fphar.2016.00432

57. Alvarez-Erviti L, Seow Y, Yin H, Betts C, Lakhal S, Wood MJ. Delivery of siRNA to the mouse brain by systemic injection of targeted exosomes. Nat Biotechnol (2011) 29:341-5. doi:10.1038/nbt.1807

58. Feng D, Zhao W-L, Ye Y-Y, Bai X-C, Liu R-Q, Chang L-F, et al. Cellular internalization of exosomes occurs through phagocytosis. Traffic (2010) 11:675-87. doi:10.1111/j.1600-0854.2010.01041.x

59. Escrevente C, Keller S, Altevogt P, Costa J. Interaction and uptake of exosomes by ovarian cancer cells. BMC Cancer (2011) 11:108. doi:10.1186/ 1471-2407-11-108

60. Svensson KJ, Christianson HC, Wittrup A, Bourseau-Guilmain E, Lindqvist E, Svensson LM, et al. Exosome uptake depends on ERK1/2-heat shock protein 27 signaling and lipid Raft-mediated endocytosis negatively regulated by caveolin-1. J Biol Chem (2013) 288:17713-24. doi:10.1074/jbc.M112.445403 
61. Tian T, Zhu YL, Hu FH, Wang YY, Huang NP, Xiao ZD. Dynamics of exosome internalization and trafficking. J Cell Physiol (2013) 228:1487-95. doi:10.1002/jcp. 24304

62. Holder B, Jones T, Sancho Shimizu V, Rice TF, Donaldson B, Bouqueau $\mathrm{M}$, et al. Macrophage exosomes induce placental inflammatory cytokines: a novel mode of maternal-placental messaging. Traffic (2016) 17:168-78. doi:10.1111/tra.12352

63. Nanbo A, Kawanishi E, Yoshida R, Yoshiyama H. Exosomes derived from Epstein-Barr virus-infected cells are internalized via caveola-dependent endocytosis and promote phenotypic modulation in target cells. J Virol (2013) 87:10334-47. doi:10.1128/JVI.01310-13

64. Tian T, Zhu Y-L, Zhou Y-Y, Liang G-F, Wang Y-Y, Hu F-H, et al. Exosome uptake through clathrin-mediated endocytosis and macropinocytosis and mediating miR-21 delivery. J Biol Chem (2014) 289:22258-67. doi:10.1074/ jbc.M114.588046

65. Segura E, Guérin C, Hogg N, Amigorena S, Théry C. CD8+ dendritic cells use LFA-1 to capture MHC-peptide complexes from exosomes in vivo. J Immunol (2007) 179:1489-96. doi:10.4049/jimmunol.179.3.1489

66. Nolte-'t Hoen EN, Buschow SI, Anderton SM, Stoorvogel W, Wauben MH. Activated T cells recruit exosomes secreted by dendritic cells via LFA-1. Blood (2009) 113:1977-81. doi:10.1182/blood-2008-08-174094

67. Munich S, Sobo-Vujanovic A, Buchser WJ, Beer-Stolz D, Vujanovic NL. Dendritic cell exosomes directly kill tumor cells and activate natural killer cells via TNF superfamily ligands. Oncoimmunology (2012) 1:1074-83. doi:10.4161/onci.20897

68. An T, Qin S, Xu Y, Tang Y, Huang Y, Situ B, et al. Exosomes serve as tumour markers for personalized diagnostics owing to their important role in cancer metastasis. J Extracell Vesicles (2015) 4:27522. doi:10.3402/jev.v4.27522

69. Hannafon BN, Trigoso YD, Calloway CL, Zhao YD, Lum DH, Welm AL, et al. Plasma exosome microRNAs are indicative of breast cancer. Breast Cancer Res (2016) 18:90. doi:10.1186/s13058-016-0753-x

70. Hosseini M, Khatamianfar S, Hassanian SM, Nedaeinia R, Shafiee M, Maftouh M, et al. Exosome-encapsulated microRNAs as potential circulating biomarkers in colon cancer. Curr Pharm Des (2016) 23(11):1705-9. doi:10.2174/1381612822666161201144634

71. Aswad H, Forterre A, Wiklander OP, Vial G, Danty-Berger E, Jalabert A, et al. Exosomes participate in the alteration of muscle homeostasis during lipid-induced insulin resistance in mice. Diabetologia (2014) 57:2155-64. doi:10.1007/s00125-014-3337-2

72. Wang L, Zhang B, Zheng W, Kang M, Chen Q, Qin W, et al. Exosomes derived from pancreatic cancer cells induce insulin resistance in C2C12 myotube cells through the PI3K/Akt/FoxO1 pathway. Sci Rep (2017) 7:5384. doi:10.1038/ s41598-017-05541-4

73. Jalabert A, Vial G, Guay C, Wiklander OPB, Nordin JZ, Aswad H, et al. Exosome-like vesicles released from lipid-induced insulin-resistant muscles modulate gene expression and proliferation of beta recipient cells in mice. Diabetologia (2016) 59:1049-58. doi:10.1007/s00125-016-3882-y

74. Deng ZB, Poliakov A, Hardy RW, Clements R, Liu C, Liu Y, et al. Adipose tissue exosome-like vesicles mediate activation of macrophage-induced insulin resistance. Diabetes (2009) 58:2498-505. doi:10.2337/db09-0216

75. Chim SS, Shing TK, Hung EC, Leung TY, Lau TK, Chiu RW, et al. Detection and characterization of placental microRNAs in maternal plasma. Clin Chem (2008) 54:482-90. doi:10.1373/clinchem.2007.097972

76. Donker RB, Mouillet JF, Chu T, Hubel CA, Stolz DB, Morelli AE, et al. The expression profile of C19MC microRNAs in primary human trophoblast cells and exosomes. Mol Hum Reprod (2012) 18:417-24. doi:10.1093/molehr/gas013

77. Ishibashi O, Ali MM, Takeshita T, Takizawa T. Placental exosome-assoicated MicroRNAs in normal pregnancy and preeclampsia. JNippon Med Sch (2011) 78:48-9. doi:10.1272/jnms.78.48

78. Almohammadi D, Casper J, Elfeky O, Chang C, Scholz-Romero K, Longo S, et al. C19MC miRNA signatures of placenta-derived exosomes in women diagnosed with gestational diabetes mellitus. Diabetes Program Genes Gestation (2016).

79. Luo SS, Ishibashi O, Ishikawa G, Ishikawa T, Katayama A, Mishima T, et al. Human villous trophoblasts express and secrete placenta-specific microRNAs into maternal circulation via exosomes. Biol Reprod (2009) 81:717-29. doi:10.1095/biolreprod.108.075481

80. Karolina DS, Tavintharan S, Armugam A, Sepramaniam S, Pek SLT, Wong MTK, et al. Circulating miRNA profiles in patients with metabolic syndrome. J Clin Endocrinol Metab (2012) 97:E2271-6. doi:10.1210/ jc.2012-1996

81. Goldie BJ, Dun MD, Lin M, Smith ND, Verrills NM, Dayas CV, et al. Activityassociated miRNA are packaged in Maplb-enriched exosomes released from depolarized neurons. Nucleic Acids Res (2014) 42:9195-208. doi:10.1093/nar/ gku594

82. Povero D, Eguchi A, Li H, Johnson CD, Papouchado BG, Wree A, et al. Circulating extracellular vesicles with specific proteome and liver MicroRNAs are potential biomarkers for liver injury in experimental fatty liver disease. PLoS One (2014) 9:e113651. doi:10.1371/journal.pone.0113651

83. Kucharzewska P, Christianson HC, Welch JE, Svensson KJ, Fredlund E, Ringner M, et al. Exosomes reflect the hypoxic status of glioma cells and mediate hypoxia-dependent activation of vascular cells during tumor development. Proc Natl Acad Sci U S A (2013) 110:7312-7. doi:10.1073/pnas.1220998110

84. Svensson KJ, Kucharzewska P, Christianson HC, Skold S, Lofstedt T, Johansson MC, et al. Hypoxia triggers a proangiogenic pathway involving cancer cell microvesicles and Par-2-mediated heparin-binding EGF signaling in endothelial cells. Proc Natl Acad Sci U S A (2011) 108:13147-52. doi:10.1073/pnas.1104261108

85. Fan GC. Hypoxic exosomes promote angiogenesis. Blood (2014) 124:3669-70. doi:10.1182/blood-2014-10-607846

86. King HW, Michael MZ, Gleadle JM. Hypoxic enhancement of exosome release by breast cancer cells. BMC Cancer (2012) 12:421. doi:10.1186/1471-2407-12-421

87. Li L, Li C, Wang S, Wang Z, Jiang J, Wang W, et al. Exosomes derived from hypoxic oral squamous cell carcinoma cells deliver miR-21 to normoxic cells to elicit a prometastatic phenotype. Cancer Res (2016) 76:1770-80. doi:10.1158/0008-5472.CAN-15-1625

88. Umezu T, Tadokoro H, Azuma K, Yoshizawa S, Ohyashiki K, Ohyashiki JH. Exosomal miR-135b shed from hypoxic multiple myeloma cells enhances angiogenesis by targeting factor-inhibiting HIF-1. Blood (2014) 124:3748-57. doi:10.1182/blood-2014-05-576116

89. Tadokoro H, Umezu T, Ohyashiki K, Hirano T, Ohyashiki JH. Exosomes derived from hypoxic leukemia cells enhance tube formation in endothelial cells. J Biol Chem (2013) 288:34343-51. doi:10.1074/jbc.M113.480822

90. Park JE, Tan HS, Datta A, Lai RC, Zhang H, Meng W, et al. Hypoxic tumor cell modulates its microenvironment to enhance angiogenic and metastatic potential by secretion of proteins and exosomes. Mol Cell Proteomics (2010) 9:1085-99. doi:10.1074/mcp.M900381-MCP200

91. Deep G, Panigrahi GK. Hypoxia-induced signaling promotes prostate cancer progression: exosomes role as messenger of hypoxic response in tumor microenvironment. Crit Rev Oncog (2015) 20:419-34. doi:10.1615/ CritRevOncog.v20.i5-6.130

92. Ramteke A, Ting H, Agarwal C, Mateen S, Somasagara R, Hussain A, et al. Exosomes secreted under hypoxia enhance invasiveness and stemness of prostate cancer cells by targeting adherens junction molecules. Mol Carcinog (2015) 54:554-65. doi:10.1002/mc.22124

93. Yu X, Deng L, Wang D, Li N, Chen X, Cheng X, et al. Mechanism of TNFalpha autocrine effects in hypoxic cardiomyocytes: initiated by hypoxia inducible factor lalpha, presented by exosomes. J Mol Cell Cardiol (2012) 53:848-57. doi:10.1016/j.yjmcc.2012.10.002

94. Khalyfa A, Zhang C, Khalyfa AA, Foster GE, Beaudin AE, Andrade J, et al. Effect on intermittent hypoxia on plasma exosomal micro RNA signature and endothelial function in healthy adults. Sleep (2016) 39:2077-90. doi:10.5665/ sleep. 6302

95. Salomon C, Kobayashi M, Ashman K, Sobrevia L, Mitchell MD, Rice GE. Hypoxia-induced changes in the bioactivity of cytotrophoblast-derived exosomes. PLoS One (2013) 8:e79636. doi:10.1371/journal.pone.0079636

96. Salomon C, Ryan J, Sobrevia L, Kobayashi M, Ashman K, Mitchell M, et al. Exosomal signaling during hypoxia mediates microvascular endothelial cell migration and vasculogenesis. PLoS One (2013) 8:e68451. doi:10.1371/ journal.pone.0068451

97. Sano S, Izumi Y, Yamaguchi T, Yamazaki T, Tanaka M, Shiota M, et al. Lipid synthesis is promoted by hypoxic adipocyte-derived exosomes in 3T3-L1 cells. Biochem Biophys Res Commun (2014) 445:327-33. doi:10.1016/j. bbrc.2014.01.183

98. Salomon C, Scholz-Romero K, Kobayashi M, Smith M, Duncombe G, Llanes $\mathrm{S}$, et al. Oxygen tension regulates glucose-induced biogenesis and release of different subpopulations of exosome vesicles from trophoblast cells: a gestational age profile of placental exosomes in maternal plasma 
with gestational diabetes mellitus. Placenta (2015) 36:488. doi:10.1016/j. placenta.2015.01.444

99. Rice GE, Scholz-Romero K, Sweeney E, Peiris H, Kobayashi M, Duncombe G, et al. The effect of glucose on the release and bioactivity of exosomes from first trimester trophoblast cells. JClin Endocrinol Metab (2015) 100:E1280-8. doi:10.1210/jc.2015-2270

100. Santovito D, De Nardis V, Marcantonio P, Mandolini C, Paganelli C, Vitale E, et al. Plasma exosome microRNA profiling unravels a new potential modulator of adiponectin pathway in diabetes: effect of glycemic control. J Clin Endocrinol Metab (2014) 99:E1681-5. doi:10.1210/jc.2013-3843

101. Savina A, Furlan M, Vidal M, Colombo MI. Exosome release is regulated by a calcium-dependent mechanism in K562 cells. J Biol Chem (2003) 278:20083-90. doi:10.1074/jbc.M301642200

102. Dai XQ, Plummer G, Casimir M, Kang Y, Hajmrle C, Gaisano HY, et al. SUMOylation regulates insulin exocytosis downstream of secretory granule docking in rodents and humans. Diabetes (2011) 60:838-47. doi:10.2337/ db10-0440

103. MacDonald PE, Eliasson L, Rorsman P. Calcium increases endocytotic vesicle size and accelerates membrane fission in insulin-secreting Ins-1 cells. J Cell Sci (2005) 118:5911-20. doi:10.1242/jcs.02685

104. Lappas M, Rice GE. Transcriptional regulation of the processes of human labour and delivery. Placenta (2009) 30(Suppl A):S90-5. doi:10.1016/j. placenta.2008.10.005

105. Burton GJ, Woods AW, Jauniaux E, Kingdom JC. Rheological and physiological consequences of conversion of the maternal spiral arteries for uteroplacental blood flow during human pregnancy. Placenta (2009) 30:473-82. doi:10.1016/j.placenta.2009.02.009

106. Brosens I, Robertson WB, Dixon HG. The physiological response of the vessels of the placental bed to normal pregnancy. J Pathol Bacteriol (1967) 93:569-79. doi:10.1002/path.1700930218

107. Constancia M, Angiolini E, Sandovici I, Smith P, Smith R, Kelsey G, et al. Adaptation of nutrient supply to fetal demand in the mouse involves interaction between the Igf2 gene and placental transporter systems. Proc Natl Acad Sci U S A (2005) 102:19219-24. doi:10.1073/pnas.0504468103

108. Dilworth MR, Kusinski LC, Cowley E, Ward BS, Husain SM, Constância M, et al. Placental-specific Igf2 knockout mice exhibit hypocalcemia and adaptive changes in placental calcium transport. Proc Natl Acad Sci U S A (2010) 107:3894-9. doi:10.1073/pnas.0911710107

109. Constancia M, Hemberger M, Hughes J, Dean W, Ferguson-Smith A, Fundele R, et al. Placental-specific IGF-II is a major modulator of placental and fetal growth. Nature (2002) 417:945-8. doi:10.1038/nature00819

110. Glazier JD, Cetin I, Perugino G, Ronzoni S, Grey AM, Mahendran D, et al. Association between the activity of the system A amino acid transporter in the microvillous plasma membrane of the human placenta and severity of fetal compromise in intrauterine growth restriction. Pediatr Res (1997) 42:514-9. doi:10.1203/00006450-199710000-00016

111. Swanson LD, Bewtra C. Increase in normal placental weights related to increase in maternal body mass index. J Matern Fetal Neonatal Med (2008) 21:111-3. doi:10.1080/14767050701866963

112. Martino J, Sebert S, Segura MT, García-Valdés L, Florido J, Padilla MC, et al. Maternal body weight and gestational diabetes differentially influence placental and pregnancy outcomes. J Clin Endocrinol Metab (2016) 101:59-68. doi:10.1210/jc.2015-2590

113. Ingvorsen C, Brix S, Ozanne SE, Hellgren LI. The effect of maternal inflammation on foetal programming of metabolic disease. Acta Physiol (Oxf) (2015) 214:440-9. doi:10.1111/apha.12533

114. Martin AM, Berger H, Nisenbaum R, Lausman AY, Macgarvie S, Crerar C, et al. Abdominal visceral adiposity in the first trimester predicts glucose intolerance in later pregnancy. Diabetes Care (2009) 32:1308-10. doi:10.2337/ dc09-0290

115. Challier JC, Basu S, Bintein T, Minium J, Hotmire K, Catalano PM, et al. Obesity in pregnancy stimulates macrophage accumulation and inflammation in the placenta. Placenta (2008) 29:274-81. doi:10.1016/j.placenta.2007.12.010

116. Basu S, Haghiac M, Surace P, Challier JC, Guerre-Millo M, Singh K, et al. Pregravid obesity associates with increased maternal endotoxemia and metabolic inflammation. Obesity (Silver Spring) (2011) 19:476-82. doi:10.1038/ oby. 2010.215

117. Aye IL, Lager S, Ramirez VI, Gaccioli F, Dudley DJ, Jansson T, et al. Increasing maternal body mass index is associated with systemic inflammation in the mother and the activation of distinct placental inflammatory pathways. Biol Reprod (2014) 90:129. doi:10.1095/biolreprod.113.116186

118. Stone RA, Silvis A, Jude D, Chaffin D. Increasing body mass index exacerbates inflammation in obese gravidas. Obstet Gynecol (2014) 123:81S. doi:10.1097/01.AOG.0000447406.31798.d3

119. Varastehpour A, Radaelli T, Minium J, Ortega H, Herrera E, Catalano P, et al. Activation of phospholipase A2 is associated with generation of placental lipid signals and fetal obesity. J Clin Endocrinol Metab (2006) 91:248-55. doi:10.1210/jc.2005-0873

120. Masuzaki H, Ogawa Y, Sagawa N, Hosoda K, Matsumoto T, Mise H, et al. Nonadipose tissue production of leptin: leptin as a novel placenta- derived hormone in humans. Nat Med (1997) 3:1029-33. doi:10.1038/nm0997-1029

121. Sattar N, Greer IA, Pirwani I, Gibson J, Wallace AM. Leptin levels in pregnancy: marker for fat accumulation and mobilization? Acta Obstet Gynecol Scand (1998) 77:278-83. doi:10.1034/j.1600-0412.1998.770304.x

122. Farley DM, Choi J, Dudley DJ, Li C, Jenkins SL, Myatt L, et al. Placental amino acid transport and placental leptin resistance in pregnancies complicated by maternal obesity. Placenta (2010) 31:718-24. doi:10.1016/j. placenta.2010.06.006

123. Saben J, Lindsey F, Zhong Y, Thakali K, Badger TM, Andres A, et al. Maternal obesity is associated with a lipotoxic placental environment. Placenta (2014) 35:171-7. doi:10.1016/j.placenta.2014.01.003

124. Mishra S, Rao CR, Shetty A. Trends in the diagnosis of gestational diabetes mellitus. Scientifica (Cairo) (2016) 2016:5489015. doi:10.1155/2016/5489015

125. Garrison A. Screening, diagnosis, and management of gestational diabetes mellitus. Am Fam Physician (2015) 91:460-7.

126. Lain KY, Catalano PM. Metabolic changes in pregnancy. Clin Obstet Gynecol (2007) 50:938-48. doi:10.1097/GRF.0b013e31815a5494

127. Barbour LA, Shao J, Qiao L, Pulawa LK, Jensen DR, Bartke A, et al. Human placental growth hormone causes severe insulin resistance in transgenic mice. Am J Obstet Gynecol (2002) 186:512-7. doi:10.1067/mob.2002.121256

128. Gaither K, Quraishi AN, Illsley NP. Diabetes alters the expression and activity of the human placental GLUT1 glucose transporter. J Clin Endocrinol Metab (1999) 84:695-701. doi:10.1210/jc.84.2.695

129. Muralimanoharan S, Maloyan A, Myatt L. Mitochondrial function and glucose metabolism in the placenta with gestational diabetes mellitus: role of miR-143. Clin Sci (Lond) (2016) 130:931-41. doi:10.1042/CS20160076

130. Visiedo F, Bugatto F, Quintero-Prado R, Cózar-Castellano I, Bartha JL, Perdomo G. Glucose and fatty acid metabolism in placental explants from pregnancies complicated with gestational diabetes mellitus. Reprod Sci (2015) 22:798-801. doi:10.1177/1933719114561558

131. Lepercq J, Cauzac M, Lahlou N, Timsit J, Girard J, Auwerx J, et al. Overexpression of placental leptin in diabetic pregnancy: a critical role for insulin. Diabetes (1998) 47:847-50. doi:10.2337/diabetes.47.5.847

132. Radaelli T, Varastehpour A, Catalano P, Hauguel-De Mouzon S. Gestational diabetes induces placental genes for chronic stress and inflammatory pathways. Diabetes (2003) 52:2951-8. doi:10.2337/diabetes.52.12.2951

133. Kuzmicki M, Telejko B, Wawrusiewicz-Kurylonek N, Citko A, Lipinska D, Pliszka J, et al. The expression of suppressor of cytokine signaling 1 and 3 in fat and placental tissue from women with gestational diabetes. Gynecol Endocrinol (2012) 28:841-4. doi:10.3109/09513590.2012.683055

134. Salomon C, Yee S, Sarker S, Scholz K, Duncombe G, Perez-Sepulveda A, et al. Placenta-derived exosomes promote trophoblast invasion and spiral arterial remodeling - a possible role in the physiopathology of preeclampsia. Reprod Sci (2015) 22:290a. doi:10.1177/1933719115579631

135. Sarker S, Scholz-Romero K, Perez A, Illanes SE, Mitchell MD, Rice GE, et al. Placenta-derived exosomes continuously increase in maternal circulation over the first trimester of pregnancy. J Transl Med (2014) 12:204. doi:10.1186/1479-5876-12-204

136. Ouyang Y, Bayer A, Chu T, Tyurin VA, Kagan VE, Morelli AE, et al. Isolation of human trophoblastic extracellular vesicles and characterization of their cargo and antiviral activity. Placenta (2016) 47:86-95. doi:10.1016/j. placenta.2016.09.008

137. Salomon C, Torres MJ, Kobayashi M, Scholz-Romero K, Sobrevia L, Dobierzewska A, et al. A gestational profile of placental exosomes in maternal plasma and their effects on endothelial cell migration. PLoS One (2014) 9:e98667. doi:10.1371/journal.pone.0098667

138. Sabapatha A, Gercel-Taylor C, Taylor DD. Specific isolation of placentaderived exosomes from the circulation of pregnant women and their 
immunoregulatory consequences. Am J Reprod Immunol (2006) 56:345-55. doi:10.1111/j.1600-0897.2006.00435.x

139. Orozco AF, Lewis DE. Flow cytometric analysis of circulating microparticles in plasma. Cytometry A (2010) 77:502-14. doi:10.1002/cyto.a.20886

140. Kshirsagar SK, Alam SM, Jasti S, Hodes H, Nauser T, Gilliam M, et al. Immunomodulatory molecules are released from the first trimester and term placenta via exosomes. Placenta (2012) 33:982-90. doi:10.1016/j. placenta.2012.10.005

141. Tolosa JM, Schjenken JE, Clifton VL, Vargas A, Barbeau B, Lowry P, et al. The endogenous retroviral envelope protein syncytin-1 inhibits LPS/PHAstimulated cytokine responses in human blood and is sorted into placental exosomes. Placenta (2012) 33:933-41. doi:10.1016/j.placenta.2012.08.004

142. Dragovic RA, Southcombe JH, Tannetta DS, Redman CW, Sargent IL. Multicolor flow cytometry and nanoparticle tracking analysis of extracellular vesicles in the plasma of normal pregnant and pre-eclamptic women. Biol Reprod (2013) 89:151. doi:10.1095/biolreprod.113.113266

143. Lok CA, Van Der Post JA, Sargent IL, Hau CM, Sturk A, Boer K, et al. Changes in microparticle numbers and cellular origin during pregnancy and preeclampsia. Hypertens Pregnancy (2008) 27:344-60. doi:10.1080/10641950801955733

144. Salomon C, Scholz-Romero K, Sarker S, Sweeney E, Kobayashi M, Correa P, et al. Gestational diabetes mellitus is associated with changes in the concentration and bioactivity of placenta-derived exosomes in maternal circulation across gestation. Diabetes (2016) 65:598-609. doi:10.2337/db15-0966

145. Elfeky O, Longo S, Lai A, Rice GE, Salomon C. Influence of maternal BMI on the exosomal profile during gestation and their role on maternal systemic inflammation. Placenta (2017) 50:60-9. doi:10.1016/j.placenta.2016.12.020

146. Pineles BL, Romero R, Montenegro D, Tarca AL, Han YM, Kim YM, et al. Distinct subsets of microRNAs are expressed differentially in the human placentas of patients with preeclampsia. Am J Obstet Gynecol (2007) 196: 261.e1-6. doi:10.1016/j.ajog.2007.01.008

147. Maccani MA, Padbury JF, Marsit CJ. miR-16 and miR-21 expression in the placenta is associated with fetal growth. PLoS One (2011) 6:e21210. doi:10.1371/journal.pone.0021210

148. Zhao C, Dong J, Jiang T, Shi Z, Yu B, Zhu Y, et al. Early second-trimester serum miRNA profiling predicts gestational diabetes mellitus. PLoS One (2011) 6:e23925. doi:10.1371/journal.pone.0023925

149. Green H, Kehinde O. Sublines of mouse $3 \mathrm{~T} 3$ cells that accumulate lipid. Cell (1974) 1:113-6. doi:10.1016/0092-8674(74)90126-3

150. Green H, Kehinde O. Spontaneous heritable changes leading to increased adipose conversion in 3T3 cells. Cell (1976) 7:105-13. doi:10.1016/0092-8674 (76) $90260-9$

151. Taylor SM, Jones PA. Multiple new phenotypes induced in 10T12 and 3T3 cells treated with 5-azacytidine. Cell (1979) 17:771-9. doi:10.1016/0092-8674 (79) $90317-9$

152. Konieczny SF, Emerson CP. 5-azacytidine induction of stable mesodermal stem cell lineages from 10T1/2 cells: evidence for regulatory genes controlling determination. Cell (1984) 38:791-800. doi:10.1016/0092-8674(84)90274-5

153. Matthias A, Ohlson KBE, Fredriksson JM, Jacobsson A, Nedergaard J, Cannon B. Thermogenic responses in brown fat cells are fully UCP1dependent: UCP2 or UCP3 do not substitute for UCP1 in adrenergically or fatty acid-induced thermogenesis. J Biol Chem (2000) 275:25073-81. doi:10.1074/jbc.M000547200

154. Aherne W, Hull D. Brown adipose tissue and heat production in the newborn infant. J Pathol Bacteriol (1966) 91:223-34. doi:10.1002/path.1700910126

155. Cypess AM, White AP, Vernochet C, Schulz TJ, Xue R, Sass CA, et al. Anatomical localization, gene expression profiling and functional characterization of adult human neck brown fat. Nat Med (2013) 19:635-9. doi: $10.1038 / \mathrm{nm} .3112$

156. Lidell ME, Betz MJ, Dahlqvist Leinhard O, Heglind M, Elander L, Slawik M, et al. Evidence for two types of brown adipose tissue in humans. Nat Med (2013) 19:631-4. doi:10.1038/nm.3017

157. Chiba S, Katsuragi I, Shimada T, Adachi I, Satoh Y, Noguchi H, et al. Evaluation of human brown adipose tissue using positron emission tomography, computerized tomography and histochemical studies in association with body mass index, visceral fat accumulation and insulin resistance. Obes $\operatorname{Rev}(2006)$ 7:87.

158. van Marken Lichtenbelt WD, Vanhommerig JW, Smulders NM, Drossaerts JM, Kemerink GJ, Bouvy ND, et al. Cold-activated brown adipose tissue in healthy men. N Engl J Med (2009) 360:1500-8. doi:10.1056/NEJMoa0808718
159. Esteve Ràfols $M$. Adipose tissue: cell heterogeneity and functional diversity. Endocrinol Nutr (2014) 61:100-12. doi:10.1016/j.endoen.2014.02.001

160. Dani C, Billon N. Adipocyte precursors: developmental origins, self-renewal, and plasticity. In: Symonds ME, editor. Adipose Tissue Biology. New York, NY: Springer (2012). p. 1-16.

161. Fain JN, Bahouth SW, Madan AK. TNFalpha release by the nonfat cells of human adipose tissue. Int J Obes Relat Metab Disord (2004) 28:616-22. doi:10.1038/sj.ijo.0802594

162. Fain JN, Cheema PS, Bahouth SW, Lloyd Hiler M. Resistin release by human adipose tissue explants in primary culture. Biochem Biophys Res Commun (2003) 300:674-8. doi:10.1016/S0006-291X(02)02864-4

163. Fain JN, Madan AK, Hiler ML, Cheema P, Bahouth SW. Comparison of the release of adipokines by adipose tissue, adipose tissue matrix, and adipocytes from visceral and subcutaneous abdominal adipose tissues of obese humans. Endocrinology (2004) 145:2273-82. doi:10.1210/en.2003-1336

164. Brabant G, Nave H, Mayr B, Behrend M, Van Harmelen V, Arner P. Secretion of free and protein-bound leptin from subcutaneous adipose tissue of lean and obese women. J Clin Endocrinol Metab (2002) 87:3966-70. doi:10.1210/ jcem.87.8.8758

165. Sinha MK, Opentanova I, Ohannesian JP, Kolaczynski JW, Heiman ML, Hale J, et al. Evidence of free and bound leptin in human circulation. Studies in lean and obese subjects and during short-term fasting. J Clin Invest (1996) 98:1277-82. doi:10.1172/JCI118913

166. Scherer PE, Williams S, Fogliano M, Baldini G, Lodish HF. A novel serum protein similar to C1q, produced exclusively in adipocytes. J Biol Chem (1995) 270:26746-9. doi:10.1074/jbc.270.45.26746

167. Kern PA, Di Gregorio GB, Lu T, Rassouli N, Ranganathan G. Adiponectin expression from human adipose tissue: relation to obesity, insulin resistance, and tumor necrosis factor-alpha expression. Diabetes (2003) 52:1779-85. doi:10.2337/diabetes.52.7.1779

168. Berg AH, Combs TP, Du X, Brownlee M, Scherer PE. The adipocytesecreted protein Acrp30 enhances hepatic insulin action. Nat Med (2001) 7:947-53. doi:10.1038/90992

169. Yamauchi T, Kamon J, Waki H, Terauchi Y, Kubota N, Hara K, et al. The fat-derived hormone adiponectin reverses insulin resistance associated with both lipoatrophy and obesity. Nat Med (2001) 7:941-6. doi:10.1038/90984

170. Yamauchi T, Kamon J, Minokoshi Y, Ito Y, Waki H, Uchida S, et al. Adiponectin stimulates glucose utilization and fatty-acid oxidation by activating AMPactivated protein kinase. Nat Med (2002) 8:1288-95. doi:10.1038/nm788

171. Yamauchi T, Nio Y, Maki T, Kobayashi M, Takazawa T, Iwabu M, et al. Targeted disruption of AdipoR1 and AdipoR2 causes abrogation of adiponectin binding and metabolic actions. Nat Med (2007) 13:332-9. doi:10.1038/nm1557

172. Jo J, Gavrilova O, Pack S, Jou W, Mullen S, Sumner AE, et al. Hypertrophy and/or hyperplasia: dynamics of adipose tissue growth. PLoS Comput Biol (2009) 5:e1000324. doi:10.1371/journal.pcbi.1000324

173. Salans LB, Cushman SW, Weismann RE. Adipose cell size and number in nonobese and obese patients. JClin Invest (1973) 52:929-41. doi:10.1172/ JCI107258

174. Salans LB, Horton ES, Sims EA. Experimental obesity in man: cellular character of the adipose tissue. J Clin Invest (1971) 50:1005-11. doi:10.1172/ JCI106570

175. Gregor MF, Hotamisligil GS. Inflammatory mechanisms in obesity. Annu Rev Immunol (2011) 29:415-45. doi:10.1146/annurev-immunol031210-101322

176. Wannamethee SG, Lowe GDO, Rumley A, Cherry L, Whincup PH, Sattar N. Adipokines and risk of type 2 diabetes in older men. Diabetes Care (2007) 30:1200-5. doi:10.2337/dc06-2416

177. Hu E, Liang P, Spiegelman BM. AdipoQ is a novel adipose-specific gene dysregulated in obesity. J Biol Chem (1996) 271:10697-703. doi:10.1074/ jbc.271.18.10697

178. Kim AY, Park YJ, Pan X, Shin KC, Kwak S-H, Bassas AF, et al. Obesity-induced DNA hypermethylation of the adiponectin gene mediates insulin resistance. Nat Commun (2015) 6:7585. doi:10.1038/ncomms8585

179. Nayak BS, Ramsingh D, Gooding S, Legall G, Bissram S, Mohammed A, et al. Plasma adiponectin levels are related to obesity, inflammation, blood lipids and insulin in type 2 diabetic and non-diabetic Trinidadians. Prim Care Diabetes (2010) 4:187-92. doi:10.1016/j.pcd.2010.05.006 
180. Tsuchida A, Yamauchi T, Ito Y, Hada Y, Maki T, Takekawa S, et al. Insulin/ Foxol pathway regulates expression levels of adiponectin receptors and adiponectin sensitivity. J Biol Chem (2004) 279:30817-22. doi:10.1074/jbc. M402367200

181. Rasmussen MS, Lihn AS, Pedersen SB, Bruun JM, Rasmussen M, Richelsen B. Adiponectin receptors in human adipose tissue: effects of obesity, weight loss, and fat depots. Obesity (2006) 14:28-35. doi:10.1038/oby.2006.5

182. Muller G, Ertl J, Gerl M, Preibisch G. Leptin impairs metabolic actions of insulin in isolated rat adipocytes. J Biol Chem (1997) 272:10585-93. doi:10.1074/jbc.272.16.10585

183. Hotamisligil G, Shargill N, Spiegelman B. Adipose expression of tumor necrosis factor-alpha: direct role in obesity-linked insulin resistance. Science (1993) 259:87-91. doi:10.1126/science.7678183

184. Amrani A, Jafarian-Tehrani M, Mormède P, Durant S, Pleau J-M, Haour F, et al. Interleukin-1 effect on glycemia in the non-obese diabetic mouse at the pre-diabetic stage. J Endocrinol (1996) 148:139-48. doi:10.1677/ joe.0.1480139

185. Sartipy P, Loskutoff DJ. Monocyte chemoattractant protein 1 in obesity and insulin resistance. Proc Natl Acad Sci U S A (2003) 100:7265-70. doi:10.1073/ pnas. 1133870100

186. Lumeng CN, Bodzin JL, Saltiel AR. Obesity induces a phenotypic switch in adipose tissue macrophage polarization. J Clin Invest (2007) 117:175-84. doi:10.1172/JCI29881

187. Xu H, Barnes GT, Yang Q, Tan G, Yang D, Chou CJ, et al. Chronic inflammation in fat plays a crucial role in the development of obesity-related insulin resistance. J Clin Invest (2003) 112:1821-30. doi:10.1172/JCI200319451

188. Sidebottom AC, Brown JE, Jacobs DR Jr. Pregnancy-related changes in body fat. Eur J Obstet Gynecol Reprod Biol (2001) 94:216-23. doi:10.1016/ S0301-2115(00)00329-8

189. Sohlstrom A, Forsum E. Changes in adipose tissue volume and distribution during reproduction in Swedish women as assessed by magnetic resonance imaging. Am J Clin Nutr (1995) 61:287-95.

190. Hoffstedt J, Arner E, Wahrenberg H, Andersson DP, Qvisth V, Lofgren P, et al. Regional impact of adipose tissue morphology on the metabolic profile in morbid obesity. Diabetologia (2010) 53:2496-503. doi:10.1007/ s00125-010-1889-3

191. Veilleux A, Caron-Jobin M, Noel S, Laberge PY, Tchernof A. Visceral adipocyte hypertrophy is associated with dyslipidemia independent of body composition and fat distribution in women. Diabetes (2011) 60:1504-11. doi:10.2337/db10-1039

192. Kim JI, Huh JY, Sohn JH, Choe SS, Lee YS, Lim CY, et al. Lipid-overloaded enlarged adipocytes provoke insulin resistance independent of inflammation. Mol Cell Biol (2015) 35:1686-99. doi:10.1128/MCB.01321-14

193. Tumurbaatar B, Poole AT, Olson G, Makhlouf M, Sallam HS, Thukuntla S, et al. Adipose tissue insulin resistance in gestational diabetes. Metab Syndr Relat Disord (2017) 15:86-92. doi:10.1089/met.2016.0124

194. Fain JN, Tagele BM, Cheema P, Madan AK, Tichansky DS. Release of 12 adipokines by adipose tissue, nonfat cells, and fat cells from obese women. Obesity (Silver Spring) (2010) 18:890-6. doi:10.1038/oby.2009.335

195. Briana DD, Malamitsi-Puchner A. Reviews: adipocytokines in normal and complicated pregnancies. Reprod Sci (2009) 16:921-37. doi:10.1177/ 1933719109336614

196. Ategbo JM, Grissa O, Yessoufou A, Hichami A, Dramane KL, Moutairou K, et al. Modulation of adipokines and cytokines in gestational diabetes and macrosomia. J Clin Endocrinol Metab (2006) 91:4137-43. doi:10.1210/jc.2006-0980

197. Kautzky-Willer A, Pacini G, Tura A, Bieglmayer C, Schneider B, Ludvik B, et al. Increased plasma leptin in gestational diabetes. Diabetologia (2001) 44:164-72. doi:10.1007/s001250051595

198. Cseh K, Baranyi E, Melczer Z, Kaszas E, Palik E, Winkler G. Plasma adiponectin and pregnancy-induced insulin resistance. Diabetes Care (2004) 27:274-5. doi:10.2337/diacare.27.1.274

199. Ogawa R, Tanaka C, Sato M, Nagasaki H, Sugimura K, Okumura K, et al. Adipocyte-derived microvesicles contain RNA that is transported into macrophages and might be secreted into blood circulation. Biochem Biophys Res Commun (2010) 398:723-9. doi:10.1016/j.bbrc.2010.07.008

200. Koeck ES, Iordanskaia T, Sevilla S, Ferrante SC, Hubal MJ, Freishtat RJ, et al. Adipocyte exosomes induce transforming growth factor beta pathway dysregulation in hepatocytes: a novel paradigm for obesity-related liver disease. J Surg Res (2014) 192:268-75. doi:10.1016/j.jss.2014.06.050
201. Lin R, Wang S, Zhao RC. Exosomes from human adipose-derived mesenchymal stem cells promote migration through Wnt signaling pathway in a breast cancer cell model. Mol Cell Biochem (2013) 383:13-20. doi:10.1007/ s11010-013-1746-z

202. Patel RS, Carter G, El Bassit G, Patel AA, Cooper DR, Murr M, et al. Adipose-derived stem cells from lean and obese humans show depot specific differences in their stem cell markers, exosome contents and senescence: role of protein kinase C delta (PKC $\delta$ ) in adipose stem cell niche. Stem Cell Invest (2016) 3:2. doi:10.3978/j.issn.2306-9759.2016.01.02

203. Durcin M, Fleury A, Taillebois E, Hilairet G, Krupova Z, Henry C, et al. Characterisation of adipocyte-derived extracellular vesicle subtypes identifies distinct protein and lipid signatures for large and small extracellular vesicles. J Extracell Vesicles (2017) 6:1305677. doi:10.1080/20013078.2017.1 305677

204. Lazar I, Clement E, Dauvillier S, Milhas D, Ducoux-Petit M, Legonidec S, et al. Adipocyte exosomes promote melanoma aggressiveness through fatty acid oxidation: a novel mechanism linking obesity and cancer. Cancer Res (2016) 76:4051-7. doi:10.1158/0008-5472.CAN-16-0651

205. Ferrante SC, Nadler EP, Pillai DK, Hubal MJ, Wang Z, Wang JM, et al. Adipocyte-derived exosomal miRNAs: a novel mechanism for obesityrelated disease. Pediatr Res (2015) 77:447-54. doi:10.1038/pr.2014.202

206. Katsuda T, Tsuchiya R, Kosaka N, Yoshioka Y, Takagaki K, Oki K, et al. Human adipose tissue-derived mesenchymal stem cells secrete functional neprilysin-bound exosomes. Sci Rep (2013) 3:1197. doi:10.1038/srep01197

207. Kranendonk ME, Visseren FL, Van Herwaarden JA, Nolte-'T Hoen EN, De Jager W, Wauben $\mathrm{MH}$, et al. Effect of extracellular vesicles of human adipose tissue on insulin signaling in liver and muscle cells. Obesity (Silver Spring) (2014) 22:2216-23. doi:10.1002/oby.20847

208. DeClercq V, D'eon B, Mcleod RS. Fatty acids increase adiponectin secretion through both classical and exosome pathways. Biochim Biophys Acta (2015) 1851:1123-33. doi:10.1016/j.bbalip.2015.04.005

209. Hosogai N, Fukuhara A, Oshima K, Miyata Y, Tanaka S, Segawa K, et al. Adipose tissue hypoxia in obesity and its impact on adipocytokine dysregulation. Diabetes (2007) 56:901-11. doi:10.2337/db06-0911

210. Kranendonk MEG, Visseren FLJ, Balkom BWM, Hoen ENMNT, Herwaarden JA, Jager W, et al. Human adipocyte extracellular vesicles in reciprocal signaling between adipocytes and macrophages. Obesity (2014) 22:1296-308. doi:10.1002/oby.20679

211. Phoonsawat W, Aoki-Yoshida A, Tsuruta T, Sonoyama K. Adiponectin is partially associated with exosomes in mouse serum. Biochem Biophys Res Commun (2014) 448:261-6. doi:10.1016/j.bbrc.2014.04.114

212. Eguchi A, Lazic M, Armando AM, Phillips SA, Katebian R, Maraka S, et al. Circulating adipocyte-derived extracellular vesicles are novel markers of metabolic stress. J Mol Med (Berl) (2016) 94:1241-53. doi:10.1007/ s00109-016-1446-8

213. Eirin A, Zhu X-Y, Puranik AS, Woollard JR, Tang H, Dasari S, et al. Comparative proteomic analysis of extracellular vesicles isolated from porcine adipose tissue-derived mesenchymal stem/stromal cells. Sci Rep (2016) 6:36120. doi:10.1038/srep36120

214. Eirin A, Zhu X-Y, Puranik AS, Woollard JR, Tang H, Dasari S, et al. Integrated transcriptomic and proteomic analysis of the molecular cargo of extracellular vesicles derived from porcine adipose tissue-derived mesenchymal stem cells. PLoS One (2017) 12:e0174303. doi:10.1371/journal.pone.0174303

215. Lee J-E, Moon P-G, Lee I-K, Baek M-C. Proteomic analysis of extracellular vesicles released by adipocytes of otsuka long-evans Tokushima fatty (OLETF) rats. Protein J (2015) 34:220-35. doi:10.1007/s10930-015-9616-z

216. Catalán V, Gómez-Ambrosi J, Rodríguez A, Silva C, Rotellar F, Gil MJ, et al. Expression of caveolin-1 in human adipose tissue is upregulated in obesity and obesity-associated type 2 diabetes mellitus and related to inflammation. Clin Endocrinol (2008) 68:213-9. doi:10.1111/j.1365-2265.2007.03021.x

217. Lee M, Liu T, Im W, Kim M. Exosomes from adipose-derived stem cells ameliorate phenotype of Huntington's disease in vitro model. Eur J Neurosci (2016) 44:2114-9. doi:10.1111/ejn.13275

218. Farinazzo A, Turano E, Marconi S, Bistaffa E, Bazzoli E, Bonetti B. Murine adipose-derived mesenchymal stromal cell vesicles: in vitro clues for neuroprotective and neuroregenerative approaches. Cytotherapy (2015) 17:571-8. doi:10.1016/j.jcyt.2015.01.005

219. Bonafede R, Scambi I, Peroni D, Potrich V, Boschi F, Benati D, et al. Exosome derived from murine adipose-derived stromal cells: neuroprotective effect on 
in vitro model of amyotrophic lateral sclerosis. Exp Cell Res (2016) 340:150-8. doi:10.1016/j.yexcr.2015.12.009

220. Blazquez R, Sanchez-Margallo FM, De La Rosa O, Dalemans W, Álvarez V, Tarazona R, et al. Immunomodulatory potential of human adipose mesenchymal stem cells derived exosomes on in vitro stimulated $\mathrm{T}$ cells. Front Immunol (2014) 5:556. doi:10.3389/fimmu.2014.00556

221. Ludwig AK, Kordelas L, Rebmann V, Radtke S, Felderhoff-Müser U, Horn PA, et al. Exosomes - from bench to bedside. Klin Padiatr (2012) 224:A6. doi: 10.1055/s-0032-1330775

222. Kranendonk MEG, Visseren FLJ, Van Balkom BWM, Nolte-'T Hoen ENM, Van Herwaarden JA, De Jager W, et al. Human adipocyte extracellular vesicles in reciprocal signaling between adipocytes and macrophages. Obesity (2014) 22:1296-308. doi:10.1002/oby.20679

223. Das SK, Balakrishnan V. Role of cytokines in the pathogenesis of nonalcoholic fatty liver disease. Indian JClin Biochem (2011) 26:202-9. doi:10.1007/s12291-011-0121-7

224. Thomou T, Mori MA, Dreyfuss JM, Konishi M, Sakaguchi M, Wolfrum C, et al. Adipose-derived circulating miRNAs regulate gene expression in other tissues. Nature (2017) 542:450-5. doi:10.1038/nature21365

225. Londono Gentile T, Lu C, Lodato PM, Tse S, Olejniczak SH, Witze ES, et al. DNMT1 is regulated by ATP-citrate lyase and maintains methylation patterns during adipocyte differentiation. Mol Cell Biol (2013) 33:3864-78. doi:10.1128/MCB.01495-12

226. Chen L, Dai Y-M, Ji C-B, Yang L, Shi C-M, Xu G-F, et al. miR-146b is a regulator of human visceral preadipocyte proliferation and differentiation and its expression is altered in human obesity. Mol Cell Endocrinol (2014) 393:65-74. doi:10.1016/j.mce.2014.05.022

227. Li M, Liu Z, Zhang Z, Liu G, Sun S, Sun C. miR-103 promotes 3T3-L1 cell adipogenesis through Akt/mTOR signal pathway with its target being MEF2D. Biol Chem (2015) 396:235-44. doi:10.1515/hsz-2014-0241

228. Epstein S, Ferrante S, Nadler E, Barberio M, Golberg M, Maltz L, et al. Obese adipocte-derived exosomal miRNAs targeting TGF- $\beta$ signaling are associated with poor asthma control. J Invest Med (2016) 64:813-4. doi:10.1136/ jim-2016-000080.33

229. Hubal MJ, Nadler EP, Ferrante SC, Barberio MD, Suh J-H, Wang J, et al. Circulating adipocyte-derived exosomal MicroRNAs associated with decreased insulin resistance after gastric bypass. Obesity (2017) 25:102-10. doi:10.1002/oby.21709

230. Silambarasan M, Tan JR, Karolina DS, Armugam A, Kaur C, Jeyaseelan K. MicroRNAs in hyperglycemia induced endothelial cell dysfunction. Int J Mol Sci (2016) 17:518. doi:10.3390/ijms17040518
231. Upadhyay R, Ding H. Differential role of microRNAs miR-221/222 and miR-103/107 in type 2 diabetes and effects of metformin (851.2). FASEB J (2014) 28.

232. Pillay P, Maharaj N, Moodley J, Mackraj I. Placental exosomes and preeclampsia: maternal circulating levels in normal pregnancies and, early and late onset pre-eclamptic pregnancies. Placenta (2016) 46:18-25. doi:10.1016/j. placenta.2016.08.078

233. Knight M, Redman CW, Linton EA, Sargent IL. Shedding of syncytiotrophoblast microvilli into the maternal circulation in pre-eclamptic pregnancies. BrJ Obstet Gynaecol (1998) 105:632-40. doi:10.1111/j.1471-0528.1998.tb10178.x

234. Baig S, Kothandaraman N, Manikandan J, Rong L, Ee KH, Hill J, et al. Proteomic analysis of human placental syncytiotrophoblast microvesicles in preeclampsia. Clin Proteomics (2014) 11:40. doi:10.1186/1559-0275-11-40

235. Tannetta DS, Hunt K, Jones CI, Davidson N, Coxon CH, Ferguson D, et al. Syncytiotrophoblast extracellular vesicles from pre-eclampsia placentas differentially affect platelet function. PLoS One (2015) 10:e0142538. doi:10.1371/journal.pone.0142538

236. Tannetta DS, Dragovic RA, Gardiner C, Redman CW, Sargent IL. Characterisation of syncytiotrophoblast vesicles in normal pregnancy and pre-eclampsia: expression of Flt-1 and endoglin. PLoS One (2013) 8:e56754. doi:10.1371/journal.pone.0056754

237. Tannetta D, Mackeen M, Kessler B, Sargent I, Redman C. OS045. Multidimensional protein identification technology analysis of syncytiotrophoblast vesicles released from perfused preeclampsia placentas. Pregnancy Hypertens (2012) 2:201-2. doi:10.1016/j.preghy.2012.04.046

238. Cronqvist T, Salje K, Familari M, Guller S, Schneider H, Gardiner C, et al. Syncytiotrophoblast vesicles show altered micro-RNA and haemoglobin content after ex-vivo perfusion of placentas with haemoglobin to mimic preeclampsia. PLoS One (2014) 9:e90020. doi:10.1371/journal.pone.0090020

Conflict of Interest Statement: The author declares that the literature review was conducted in the absence of any commercial or financial relationships that could be construed as a potential conflict of interest.

Copyright (๑) 2017 Jayabalan, Nair, Nuzhat, Rice, Zuñiga, Sobrevia, Leiva, Sanhueza, Gutiérrez, Lappas, Freeman and Salomon. This is an open-access article distributed under the terms of the Creative Commons Attribution License (CC BY). The use, distribution or reproduction in other forums is permitted, provided the original author(s) or licensor are credited and that the original publication in this journal is cited, in accordance with accepted academic practice. No use, distribution or reproduction is permitted which does not comply with these terms. 